\title{
PATENT DUCTUS ARTERIOSUS SOME NOTES ON PROGNOSIS AND ON PULMONARY HYPERTENSION
}

\author{
BY \\ MAURICE CAMPBELL \\ From the Cardiac Department, Guy's Hospital, and the Institute of Cardiology \\ Received March 21, 1955
}

Successful ligation of a patent ductus arteriosus was first reported by Gross and Hubbard in 1939. Since then an increasing number of physicians and surgeons have thought that all patients with this as the sole anomaly should be treated surgically. In this country Gilchrist (1945), in an excellent review of the subject, expressed the view that the ductus should be closed in children even with slight symptoms, and a similar view was expressed by Bourne (1945) and by East (1945). There are good reasons, because the studies of reported deaths by Bullock et al. (1939) and by Keys and Shapiro (1943) show that many patients die before 30 and still more before 40 years of age, although general experience and the follow-up studies of Wilson and Lubschez (1942) and of Benn (1947) show that the prognosis in children is excellent for many years.

The evidence for surgical closure of a ductus in every case is, however, not complete; for the natural prognosis is still uncertain and becomes more difficult to determine with the increasing proportion of children submitted to operation. The progress of older patients should help and so we have made an effort to re-examine all those over 35 years of age.

\section{General Aspects}

During the last few years we have seen 160 patients with a patent ductus, excluding 6 where there seemed to have been pulmonary hypertension from infancy with a balanced or reversed shunt (see p. 525) and excluding those with morbus cœruleus or with other abnormalities. The sex incidence shows the usual preponderance of girls with a proportion of $2 \cdot 7: 1$, the excess showing equally at all ages and 27 per cent being male and 73 per cent female. The age incidence, when they were first seen, is shown in Table I: nearly half were under 10 years of age, probably because the diagnosis is often made at the first school examination, but a quarter were over 20 and twenty have been re-examined and followed generally for some years after they had passed 35 years of age.

TABLE I

Age and Sex Incidence of Patent Ductus Arteriosus

\begin{tabular}{|c|c|c|c|c|c|c|c|c|c|}
\hline & \multicolumn{9}{|c|}{ Numbers at each age (in years) } \\
\hline & $0-4$ & $5-9$ & $10-14$ & 15-19 & $20-24$ & $25-29$ & $30-34$ & $\begin{array}{l}35 \text { and } \\
\text { over }\end{array}$ & $\begin{array}{c}\text { Total } \\
\text { number }\end{array}$ \\
\hline $\begin{array}{ll}\text { Male } & . . \\
\text { Female }\end{array}$ & $\begin{array}{r}7 \\
22\end{array}$ & $\begin{array}{l}11 \\
38\end{array}$ & $\begin{array}{r}5 \\
18\end{array}$ & $\begin{array}{r}9 \\
12\end{array}$ & $\begin{array}{l}4 \\
7\end{array}$ & $\begin{array}{l}2 \\
5\end{array}$ & $\begin{array}{l}2 \\
4\end{array}$ & $\begin{array}{r}3 \\
11\end{array}$ & $\begin{array}{r}43 \\
117\end{array}$ \\
\hline Percentage & 18 & 30 & 14 & 13 & 8 & 4 & 4 & 9 & 160 \\
\hline
\end{tabular}


We need not say much about the general features for Brown (1950) has given an excellent account. We would only comment shortly on the diagnosis and on his statement that a large heart is rare and suggests some additional abnormality. The heart is often large, sometimes very large with cardiothoracic ratios of 60 or 65 per cent, even in young children, and may return to a normal size after closure of the ductus (see Fig. 1 and 2) proving that this was the cause of the enlargement.

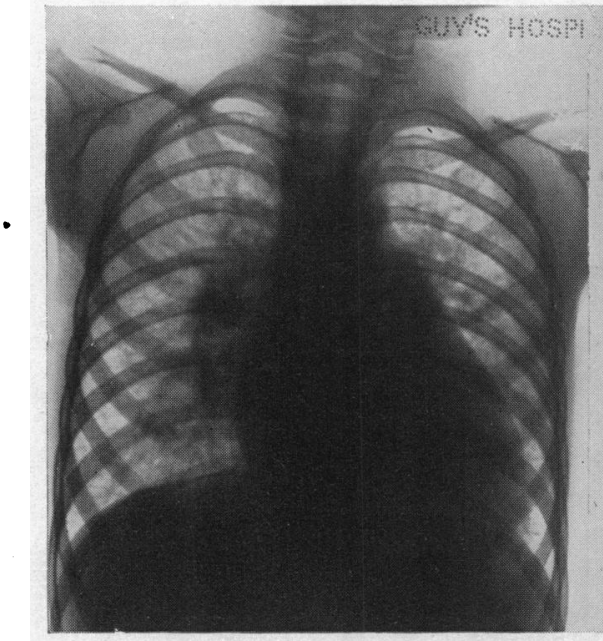

A

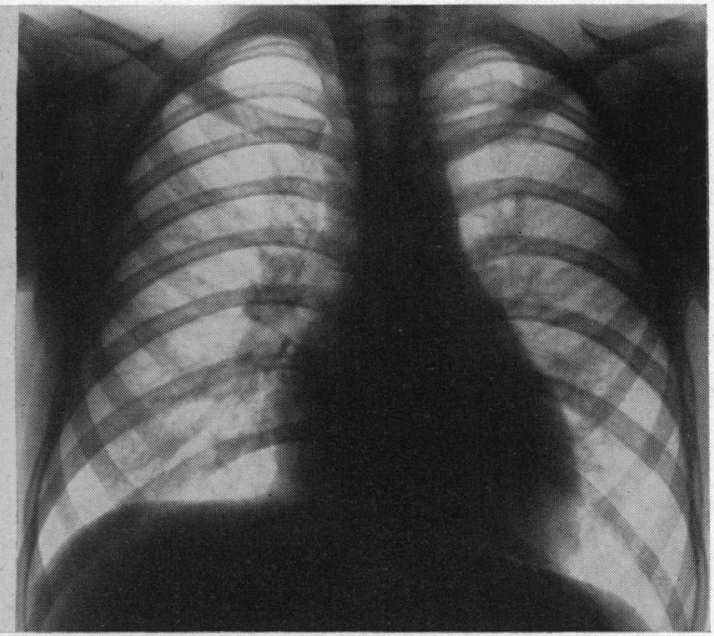

B

FIG. 1.-A very large heart, becoming normal in size after closure of an uncomplicated patent ductus. (A) Before operation, c.t.r. 63 per cent $(10 \cdot 5 / 16 \cdot 8 \mathrm{~cm}$.). (B) Four years after operation, c.t.r. 49 per cent $(11 \cdot 2 / 23.0 \mathrm{~cm}$.). From a girl, aged 5. Case P226.

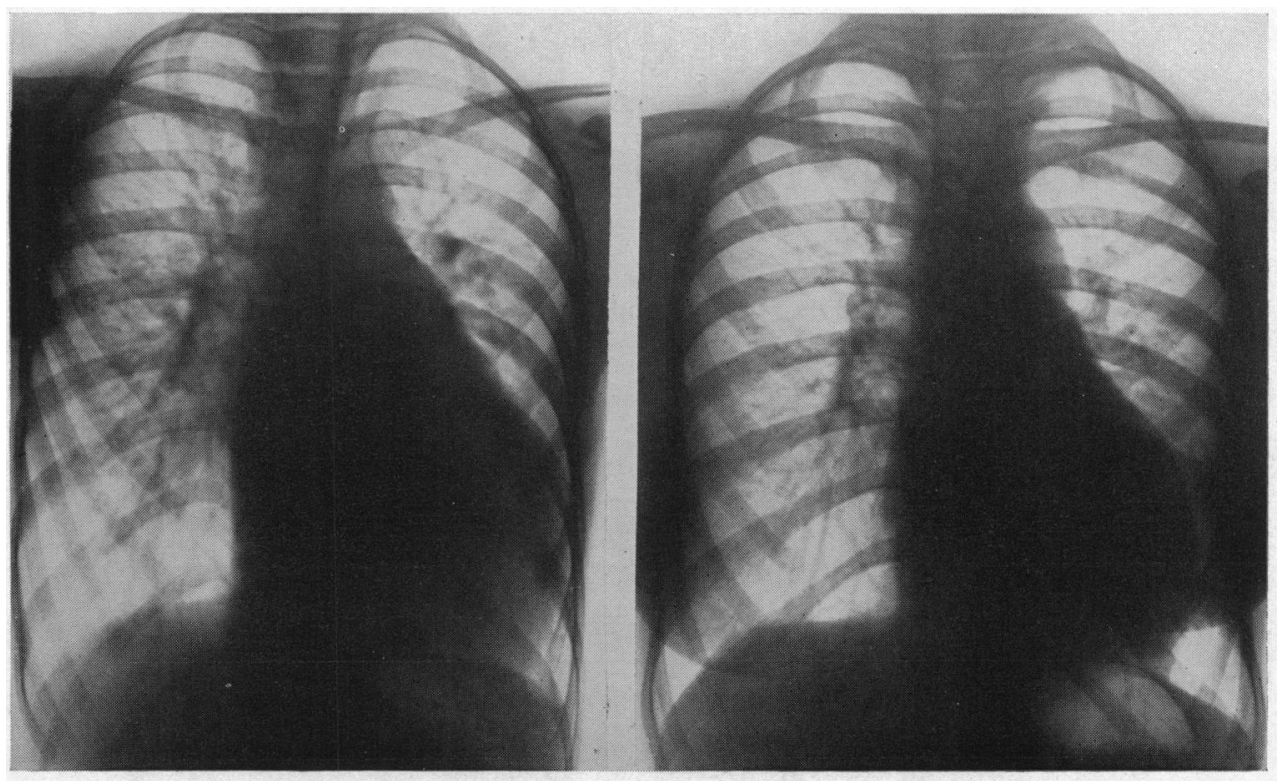

A

B

FIG. 2.-A very large heart becoming much smaller after closure of a patent ductus. (A) Before operation, c.t.r. 63 per cent $(12 \cdot 1 / 19 \cdot 3 \mathrm{~cm}$.). (B) Two years after operation, c.t.r. 54 per cent $(11 \cdot 6 / 21 \cdot 4 \mathrm{~cm}$.). From a girl, aged 12 . Case 0621 . 
We agree, of course, that often there is nothing more than some prominence of the left ventricle on radioscopy.

Diagnosis. This can be made on the continuous murmur in 95 per cent of cases. Cardiac catheterization should be used whenever there is any suggestion of right ventricular hypertrophy, to decide if this is due to pulmonary hypertension alone or to other complications, and whenever a patent ductus seems possible although the murmur is not a typical continuous one: this may apply to older patients where the murmur is disappearing or to young children before it has developed or where it is atypical. Aitken (1953) thinks this is common where there is a short wide ductus and that such children are liable to develop pulmonary hypertension. The only two young patients who have died had only systolic or atypical murmurs when they were first seen, and were waiting catheterization when they died elsewhere, one with bacterial endocarditis and one with hæmoptysis. These children emphasize the need for catheterization whenever a patent ductus seems a possible, even if unlikely, diagnosis. The continuous murmur is, however, generally reliable and few patients with long sytolic and diastolic murmurs that were not truly continuous have proved to have a patent ductus. Phonocardiography may be useful if there is doubt (Haring et al., 1954).

Catheterization is generally decisive but it may fail. It failed in two patients where the diagnosis was proved by operation, presumably because the catheter had not passed far enough into the pulmonary artery. The second possible cause of failure is when the oxygen saturation increases in the right ventricle as well as in the pulmonary artery. This may be due to the addition of pulmonary regurgitation or to a shunt through a ventricular septal defect, and can provide a difficult diagnostic problem, as in our Case 24 . Cournand et al. (1949) described one patient where a patent ductus with pulmonary regurgitation wrongly suggested that there was a ventricular septal defect and another where necropsy confirmed that both lesions were present.

Spontaneous Closure of the Ductus. A machinery murmur may regress and disappear. This happened five times in the series of Brown and Muir, once at the age of 34 after 17 years observation (Brown, 1950), and Benn (1947) reported two examples at the ages of 25 and 27 after the murmur had been observed since childhood. Our Cases 1 and 2 have nearly reached this stage and so has a young man, aged 20 , who had been successful in cross-country running in the army; the murmur was getting fainter and catheterization showed a rise of $\mathrm{O}_{2}$ percentage saturation that was not decisive, from 80 in the RA and 76 in the RV to 78 in the right and 84 per cent in the left pulmonary artery. Nevertheless, this does not happen often enough to be any reason for deferring operation, unless the patient shows signs that the ductus is already closing.

Operative Treatment and Mortality. Many of the older patients lose ground (see later) and this supports the view that all those with a patent ductus should have an operation when the diagnosis is made. Of the 160 patients, 20 who have passed the age of 35 years will be discussed fully in the next section. This leaves 140 patients under 35 years of age. Two died before the diagnosis was established and 111 have had operation for closing the ductus. There are another 10 who have been advised to have an operation and 12 who are to be seen again for a final decision. This means that there are only 5 where operation has not been advised because the shunt is thought to be so small that the ductus seems more likely to close than to cause difficulties. In two of these, though I have little doubt of the diagnosis, catheterization has failed to prove it.

Operation has been carried out in 119 patients. I have been fortunate in the surgeons available and among the ordinary patients, including eight over 35 and another fourteen over 20 years of age and several with pulmonary hypertension there has been only one death. There were, however, four deaths in more complicated cases-two where the shunt had become reversed (Case 19) or balanced (Case 28) and two where unsuccessful operations had been performed elsewhere; in one of these the ductus had recanalized (Case 23) and in the other the pulmonary artery had been ligated in error (Milstein and Brock, 1954, Case 15).

This also happened in Case 4 of Bonham-Carter et al. (1955) and nearly we think in another patient, aged 22, where nothing was done because occlusion of "the ductus " was said to be without effect on the thrill. When he was seen, clinical examination and catheterization suggested 
a ductus, and when this was closed by Mr. Tubbs, who found nothing out of the ordinary, his murmur disappeared, his heart became smaller, and he lost all his symptoms. Such examples are mentioned lest the success and low mortality of experienced surgeons should suggest that there is little risk. A very low mortality at operation is essential if it is to be advised in all patients, even when they are free from symptoms.

The patient who died was 16 , and the vessels were not easy to deal with in one girl of 17 and in two girls of 19 and 20 years. Difficulties are rarely encountered in patients under 15, but once the diagnosis has been made there is no object in deferring operation. This series does, however, show that where the opportunity has been missed at an earlier age, there is no undue risk in older patients though auricular fibrillation may occur for a time after operation.

Results of Operations. These have been excellent and we have little to add as our experience is the same as that of others in the series that have been reported. So far as we know there are only two patients who have caused anxiety afterwards: one had a cerebral abscess without evidence of bacterial endocarditis two years later and the other is the only one where the ductus has partly recanalized. She was a girl, aged 19 , with some aneurysmal dilatation of the ductus and the aorta, and Mr. Holmes Sellors was asked to carry out the operation which, as expected, was difficult. Four years later she seemed well but a fainter continuous murmur was heard again; the flow through the ductus can not have been very large for the heart was smaller than before (c.t.r. 57 instead of $64 \%$ ) but not normal. Probably this difficulty would not have arisen had the ductus been closed some years earlier: such problems are inevitable at present but should arise less often in the future.

In most cases the heart becomes normal in size or nearly so. Sometimes this happens quickly after operation but sometimes more slowly, only becoming normal as the chest grows with the child's growth, e.g. in one girl the cardiothoracic ratio fell gradually from 63 to 54 per cent in the course of three years (Fig. 2).

Although in general the operation is done to help the patients in the future rather than at once, some find they were more disabled than they thought and others find the reduction in the large pulmonary blood flow makes their liability to bronchial attacks and pulmonary congestion much less. One girl had severe asthma with frequent attacks of bronchitis and congestion, and her mother was warned that much improvement in this direction could not be promised: in fact, four years after, her asthmatic attacks are almost cured, being trivial affairs of a day or so instead of a constant cause of anxiety through the winter, and her heart is much smaller (Fig. 1).

Cardiologists are rightly reluctant to admit fatigue as an important cardiac symptom, but it must be accepted as typical of some patients with a large ductus although many have unlimited energy: such fatigue may disappear completely after a successful operation. This is in line with the suggestion of Gorlin (1954) that fatigue is common with severe mitral incompetence because of the small systemic flow.

\section{The Progress of Older Patients}

We have seen 20 patients over 35 years of age who still had or were known to have had a typical continuous murmur (see Table II). The main results obtained in those who had cardiac catheterization are given in Table IV, where the size of the shunt is expressed as a percentage of the pulmonary flow which is, of course, in the case of a patent ductus the same as the left ventricular output. For convenience in comparing results expressed as ratios of the pulmonary and systemic flows, the relationship of these two methods is shown in Table III, and this is applicable to all forms of leftto-right shunt.

We have divided these patients into five groups (1) those with the ductus almost closed, (2) those still doing well, (3) those apparently well but with a large heart or right ventricular strain, (4) those losing ground, and (5) those who have died. All had got on well in early life; 11 of the 15 women married and all but two of these had borne children without any special difficulty. 
TABLE II

Older Patients with Patent Ductus Arteriosus

\begin{tabular}{|c|c|c|c|c|c|c|c|}
\hline Case No. & $\begin{array}{l}\text { Sex and } \\
\text { age }\end{array}$ & $\begin{array}{l}\text { Heart } \\
\text { size } \\
\text { c.t.r. } \\
(\%)\end{array}$ & $\begin{array}{l}\text { Blood } \\
\text { pressur } \\
\text { and puls } \\
\text { pressur }\end{array}$ & & $\begin{array}{l}\text { Shunt as } \\
\text { percentage } \\
\text { of } L V \\
\text { output } \\
(\%)\end{array}$ & $\begin{array}{c}\text { PA } \\
\text { pressure }\end{array}$ & Electrocardiogram \\
\hline $\begin{array}{l}1(\mathrm{H} 273) \\
2(1230) \\
3(1155) \\
4(1202) \\
5(\mathrm{CB} 30)\end{array}$ & $\begin{array}{l}\text { M37-44 } \\
\text { F31-38 } \\
\text { F44 } \\
\text { F38 } \\
\text { F60-62 }\end{array}$ & $\begin{array}{l}48 \\
42 \\
51 \\
42 \\
60\end{array}$ & $\begin{array}{l}120 / 75 \\
145 / 85 \\
160 / 90 \\
145 / 85 \\
130 / 65\end{array}$ & $\begin{array}{l}45 \\
60 \\
70 \\
60 \\
65\end{array}$ & $\frac{\bar{m}}{\overline{4}}$ & $\begin{array}{l}\overline{-} \\
20 / 10 \\
23 / 10\end{array}$ & $\begin{array}{l}\text { No LVP } \\
\text { No LVP } \\
\text { LVP } \\
\text { Slight LVP } \\
\text { LVS. T inv. in I, V5, V6 (Fig. 3) }\end{array}$ \\
\hline $\begin{array}{r}6(\mathrm{O} 326) \\
7(\mathrm{O} 612) \\
8(\mathrm{H} 305) \\
9(\mathrm{P} 214) \\
10(1213) \\
11(1110)\end{array}$ & $\begin{array}{l}\text { F41-47 } \\
\text { M36-40 } \\
\text { F43-48 } \\
\text { M34-40 } \\
\text { F29-35* } \\
\text { F45* }\end{array}$ & $\begin{array}{l}57 \\
56 \\
55 \\
53 \\
68 \\
68\end{array}$ & $\begin{array}{l}180 / 80 \\
125 / 65 \\
145 / 65 \\
130 / 70 \\
130 / 50 \\
130 / 50\end{array}$ & $\begin{array}{r}100 \\
60 \\
80 \\
60 \\
80 \\
80\end{array}$ & 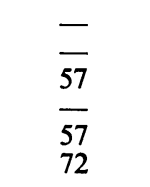 & $\begin{array}{l}\overline{7} \\
\overline{13 / 5} \\
\overline{45 / 35} \\
68 / 40\end{array}$ & $\begin{array}{l}\text { LVP only } \\
\text { LVP only } \\
\text { LVP only } \\
\text { LVS. T inv. in I } \\
\text { LVS. T inv. in V4, V5, V6 (Fig. 4) } \\
\text { LVS. T inv. in I, VL, V6 }\end{array}$ \\
\hline $\begin{array}{l}12(\mathrm{P} 318) \\
13(\mathrm{H} 328) \\
14(\mathrm{H} 303) \\
15(\mathrm{O} 582) \\
16(\mathrm{P} 342) \\
17(\mathrm{O} 332)\end{array}$ & $\begin{array}{l}\text { M42 } \\
\text { F41* } \\
\text { F35* } \\
\text { M34-38* } \\
\text { F53* } \\
\text { F28-35* }\end{array}$ & $\begin{array}{l}63 \\
50 \\
68 \\
54 \\
65 \\
69\end{array}$ & $\begin{array}{l}125 / 65 \\
170 / 60 \\
180 / 20 \\
130 / 70 \\
145 / 65 \\
140 / 70\end{array}$ & $\begin{array}{r}60 \\
110 \\
160 \\
60 \\
80 \\
70\end{array}$ & $\begin{array}{l}\overline{62} \\
64 \\
58 \\
50 \\
65\end{array}$ & $\begin{array}{c}2 \overline{22 / 11} \\
39 \text { mean } \\
45 / 25 \\
26 / 16 \\
36 / 16\end{array}$ & $\begin{array}{l}\text { LVS. T inv. in I, V6 } \\
\text { LVP. T flat in L, VI, V6 } \\
\text { LVS } \\
\text { LVP } \rightarrow \text { LVS (Fig. 6) } \\
\text { LVS } \\
\text { RVP from pulmonary stenonis }\end{array}$ \\
\hline $\begin{array}{l}18 \text { (H287) } \\
19 \text { (P177) } \\
20 \text { (H306) }\end{array}$ & $\begin{array}{l}\text { F39 } \\
\text { F40† } \\
\text { F32-38 }\end{array}$ & $\begin{array}{l}73 \\
60 \\
64\end{array}$ & $\begin{array}{l}140 / 60 \\
125 / 65 \\
180 / 20\end{array}$ & $\begin{array}{r}80 \\
60 \\
160\end{array}$ & z & $1 \overline{10 / 65}$ & $\begin{array}{l}\text { Balanced; T small in I and V6 } \\
\text { LVS. T inv. in I, VL, V4-V6. Some RVH } \\
\text { 1948 LVP; } 1954 \text { LVS. T inv. in I, VL, V5, } \\
\text { V6 }\end{array}$ \\
\hline $\begin{array}{l}21(\mathrm{O} 280) \\
22(\mathrm{P} 316) \\
23(\mathrm{P} 314) \\
24(\mathrm{O} 891)\end{array}$ & $\begin{array}{l}\text { M27* } \\
\text { M26* } \\
\text { F26† } \\
\text { F30-34) }\end{array}$ & $\begin{array}{l}48 \\
56 \\
59 \\
66\end{array}$ & $\begin{array}{l}130 / 50 \\
140 / 60 \\
160 / 60 \\
155 / 59\end{array}$ & $\begin{array}{r}80 \\
80 \\
100 \\
96\end{array}$ & $\begin{array}{l}32 \\
68 \\
70 \\
50\end{array}$ & $\begin{array}{c}18 \\
78 / 54 \\
65 / 39 \\
20 / 5\end{array}$ & $\begin{array}{l}\text { LVP only } \\
\text { Bilateral vent. hypertrophy (BVH) } \\
\text { BVH and flat or inv. T waves } \\
\text { 1952, LVP; 1955, early LVS, small T in } \\
\text { I and V6 }\end{array}$ \\
\hline
\end{tabular}

* Have had operations. † Died after operations.

TABLE III

The Size of Left-to-right Shunts Related to Systemic and Pulmonary Flows

\begin{tabular}{c|c|c|c|c}
\hline $\begin{array}{c}\text { Size of } \\
\text { shunt } \\
\text { (litre/min.) }\end{array}$ & $\begin{array}{c}\text { Shunt as } \\
\text { percentage } \\
\text { of pulmonary } \\
\text { flow } \\
(\%)\end{array}$ & $\begin{array}{c}\text { Pulmonary } \\
\text { flow } \\
\text { (litres/min.) }\end{array}$ & $\begin{array}{c}\text { Systemic } \\
\text { flow } \\
\text { (litres/min.) }\end{array}$ & $\begin{array}{c}\text { Pulmonary } \\
\text { flow/systemic } \\
\text { flow }\end{array}$ \\
\hline 2 & 33 & 6 & 4 & 1.5 \\
4 & 50 & 8 & 4 & 2.0 \\
6 & 60 & 10 & 4 & 2.5 \\
8 & 66 & 12 & 4 & 3.0 \\
12 & 75 & 20 & 4 & 5.0 \\
16 & 80 & 16 & 4 & 5.0 \\
\hline
\end{tabular}

This table is equally applicable to all uncomplicated left-to-right shunts-atrial and ventricular septal defects as well as patent ductus. It has been calculated on the assumption that the systemic flow remains constant at 4 litres a minute. 
TABLE IV

Some Findings at Cardiac Catheterization in Patients with Patent Ductus Arteriosus

\begin{tabular}{|c|c|c|c|c|c|c|c|c|c|c|c|}
\hline \multirow[b]{2}{*}{$\begin{array}{c}\text { Case } \\
\text { No. }\end{array}$} & \multirow{2}{*}{$\begin{array}{l}\text { Sex } \\
\text { and } \\
\text { age }\end{array}$} & \multicolumn{4}{|c|}{$\mathrm{O}_{2}$ percentage } & \multicolumn{3}{|c|}{ Pressures (mm. Hg) } & \multicolumn{2}{|c|}{$\begin{array}{c}\text { Flows* } \\
\text { Litres/min. }\end{array}$} & \multirow{2}{*}{$\begin{array}{c}\text { Shunt as } \\
\text { percentage } \\
\text { of } L V \\
\text { output } \\
(\%)\end{array}$} \\
\hline & & RA & RV & PA & $\begin{array}{l}\text { Syst. } \\
\text { art. }\end{array}$ & RV & PA & $\begin{array}{l}\text { Syst. } \\
\text { art. }\end{array}$ & Syst. & Pulm. & \\
\hline $\begin{array}{l}3 \\
5 \\
8 \\
10 \\
11 \\
13 \\
14 \\
15 \\
16 \\
17 \dagger \\
19\end{array}$ & $\begin{array}{l}\text { F44 } \\
\text { F60 } \\
\text { F48 } \\
\text { F35 } \\
\text { F45 } \\
\text { F41 } \\
\text { F35 } \\
\text { M38 } \\
\text { F53 } \\
\text { F35 } \\
\text { F40 }\end{array}$ & $\begin{array}{l}(86) \\
65 \\
71 \\
68 \\
53 \\
53 \\
62 \\
68 \\
60 \\
60 \\
-\end{array}$ & $\begin{array}{l}73 \\
62 \\
66 \\
71 \\
56 \\
52 \\
66 \\
65 \\
64 \\
59 \\
-\end{array}$ & $\begin{array}{l}84 \\
75 \\
86 \\
86 \\
86 \\
75 \\
88 \\
86 \\
75 \\
86 \\
-\end{array}$ & $\begin{array}{c}99 \\
97 \\
92 \\
99 \\
96 \\
(90) \\
94 \\
99 \\
95 \\
97 \\
-\end{array}$ & $\begin{array}{c}19 / 4 \\
24 / 2 \\
18 / 2 \\
55 / 5 \\
65 / 4 \\
23 / 0 \\
20 \\
45 / 6 \\
26 / 5 \\
158 / 10 \dagger \\
-\end{array}$ & $\begin{array}{c}19 / 9 \\
23 / 10 \\
13 / 5 \\
45 / 35 \\
68 / 40 \\
22 / 11 \\
39 \\
45 / 25 \\
26 / 16 \\
36 / 16 \\
110 / 65\end{array}$ & $\begin{array}{l}160 / 90 \\
130 / 65 \\
145 / 65 \\
130 / 50 \\
130 / 50 \\
170 / 60 \\
180 / 20 \\
130 / 70 \\
140 / 65 \\
140 / 70 \\
125 / 65\end{array}$ & $\begin{array}{c}3 \cdot \overline{5(2 \cdot 3)} \\
5 \cdot 3(3 \cdot 7) \\
5 \cdot 9(3 \cdot 6) \\
3 \cdot 7(2 \cdot 3) \\
4 \cdot 5(3 \cdot 2) \\
4 \cdot 0 ? \cdot \frac{1}{4 \cdot 3(2 \cdot 5)} \\
5 \cdot 1(3 \cdot 2) \\
3 \cdot 3(2 \cdot 0) \\
-\end{array}$ & $\begin{array}{l}\overline{-}- \\
6 \cdot 7(4 \cdot 5) \\
12 \cdot 5(8 \cdot 8) \\
13 \cdot 8(8 \cdot 6) \\
13 \cdot 2(8 \cdot 4) \\
11 \cdot 6(8 \cdot 3) \\
12 \cdot 0 ? \cdot-\overline{9} \\
10 \cdot 3(6 \cdot 0) \\
10 \cdot 0(6 \cdot 2) \\
10 \cdot 0(6 \cdot 0) \\
-\end{array}$ & $\begin{array}{l}-\overline{48} \\
57 \\
57 \\
72 \\
62 \\
65 \\
58 \\
48 \\
65 \\
-\end{array}$ \\
\hline $\begin{array}{l}21 \\
22 \\
23 \\
24\end{array}$ & $\begin{array}{l}\text { M27 } \\
\text { M26 } \\
\text { F26 } \\
\text { F30 }\end{array}$ & $\begin{array}{l}66 \\
59 \\
57 \\
63\end{array}$ & $\begin{array}{l}72 \\
63 \\
60 \\
80\end{array}$ & $\begin{array}{l}80 \\
83 \\
86 \\
81\end{array}$ & $\begin{array}{l}95 \\
92 \\
97 \\
96\end{array}$ & $\begin{array}{r}14 \\
77 / 3 \\
62 / 6 \\
24 / 2\end{array}$ & $\begin{array}{l}18 \\
78 / 54 \\
65 / 39 \\
20 / 5\end{array}$ & $\begin{array}{l}130 / 50 \\
140 / 60 \\
100 / 50 \\
140 / 60\end{array}$ & $\begin{array}{l}5 \cdot 2(3 \cdot 1) \\
5 \cdot 9(3 \cdot 4) \\
3 \cdot 8(2 \cdot 3) \\
5 \cdot 4(3 \cdot 6)\end{array}$ & $\begin{array}{c}7 \cdot 6(4 \cdot 4) \\
18 \cdot 5(10 \cdot 8) \\
13 \cdot 5(8 \cdot 2) \\
10 \cdot 9(7 \cdot 2)\end{array}$ & $\begin{array}{l}32 \\
68 \\
71 \\
50\end{array}$ \\
\hline
\end{tabular}

* The figures in brackets give the cardiac index (litres/sq.m./minute).

$\uparrow$ This patient had pulmonary valve stenosis as well.

\section{Older Patients with the Ductus almost Closed}

The two patients in this group were leading normal lives without symptoms. The continuous murmur was very faint and localized under the left clavicle and could easily be missed. Neither had any enlargement of the heart or ventricular preponderance in the electrocardiogram; Case 1 was the only one of the 20 older patients with a pulse pressure under $60 \mathrm{~mm}$. Neither has had catheterization but the shunt through the ductus must be small.

Case 1. A man, aged 37-44,* was leading a normal life. His continuous murmur had been missed at a previous examination for life insurance and when he had an operation, although it had been obvious when he was a boy. His earlier notes were available at the Heart Hospital and 30 years before Dr. ParsonsSmith had recorded a typical continuous murmur.

Case 2. A woman, aged 31-38, had no symptoms and was seen only because she brought up her daughter with coarctation of the aorta. Almost certainly the murmur had been much louder for a ductus had been diagnosed confidently when she was at school.

\section{Older Patients still Doing Well}

The three patients in this group were all leading normal lives, and only the woman of $60 \mathrm{com}$ plained of any symptoms or had any cardiac enlargement or left ventricular strain; she can only be included here because she had been so well till she was 50. All had continuous murmurs and pulse pressures between 60 and 70 . The two who had catheterization did not show any rise of pulmonary arterial pressure $(23 / 10$ and $26 / 10 \mathrm{~mm}$. $\mathrm{Hg})$.

Case 3. A woman, aged 44, married and with three children, was seen only because her dentist wanted an opinion about her heart. She had no cardiac symptoms and though there seemed no doubt about the diagnosis, catheterization was indecisive (see Table IV).

Case 4. A woman, aged 38, was leading a normal life without symptoms and had two children, though she had been given a bad prognosis when a child. Catheterization was refused but it seems unlikely that operation is indicated here.

Case 5. A woman, aged 60-62, had noticed some dyspnoea for ten years and had a large heart (c.t.r. $60 \%$ ) and left ventricular strain (see Fig. 3). Catheterization showed that half the left ventricular output was flowing through the ductus.

* Where two ages are given this indicates the time he has been under my observation before operation. 

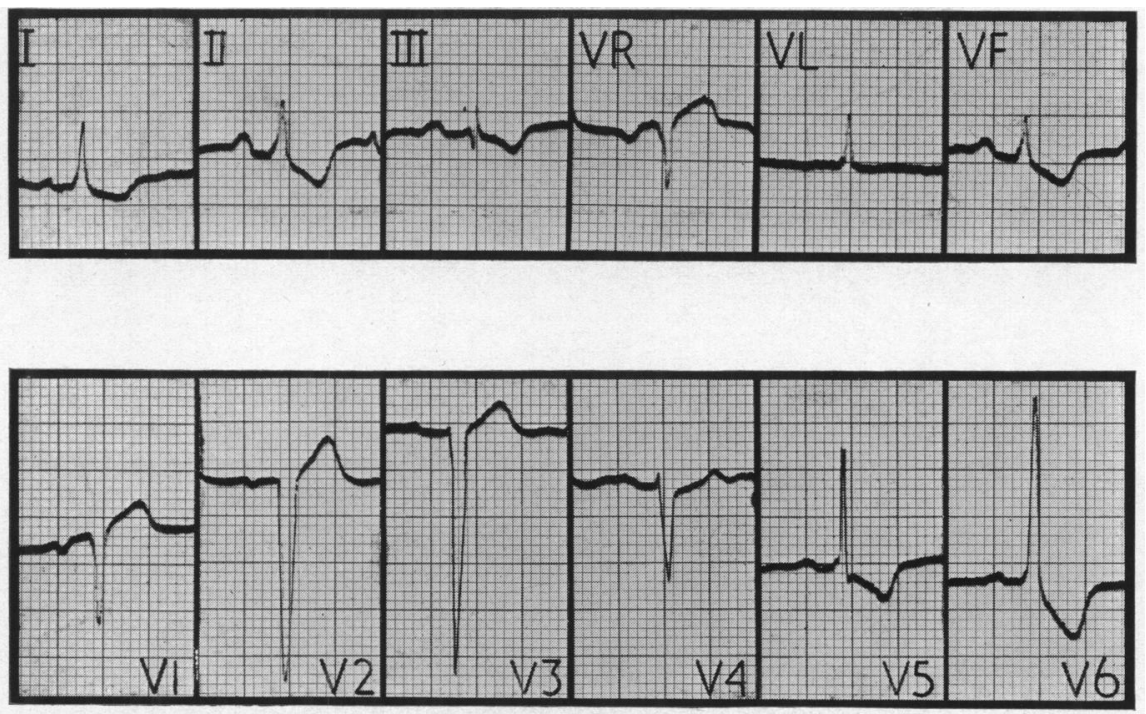

Fig. 3.-Left ventricular preponderance and strain with $\mathrm{T}$ inversion in the standard leads and in VF, V5, and V6, from a woman, aged 62, who had hardly been breathless till the last ten years. Standardization is normal, $1 \mathrm{Mv} .=1 \mathrm{~cm}$., in this and other figures unless stated otherwise. Case 5.

\section{Older Patients Apparently well but with Large Hearts or Left Ventricular Strain}

All the six patients in this group had typical continuous murmurs, except Case 11, who was losing it and generally had only a systolic murmur. All had rather wide pulse pressures from 60 to $100 \mathrm{~mm}$. and all had large hearts, the cardiothoracic ratio being over 65 per cent in two. All had left ventricular preponderance and 3 of the 6 had left ventricular strain (Fig. 4). Between 57 and 70 per cent of the left ventricular output was passing through the ductus in the three who had catheterization and the pulmonary arterial pressure was $13 / 5$ in Case $8,45 / 35$ in Case 10 , and $68 / 40 \mathrm{~mm}$. $\mathrm{Hg}$ in Case 11.

Case 6. A woman, aged 41-47, was admitted with bacterial endocarditis, having been almost symptomless up to that time. After she had made a good recovery she was advised to have an operation but refused. She has remained well for 6 years since this and her heart has not become larger (c.t.r. $57 \%$ ).

Case 7. A man, aged 36-40, had hardly any symptoms and was working as a cook. Operation was not advised and four years later there has been no increase in symptoms, heart size (c.t.r. 56\%), or left ventricular preponderance.

Case 8. A woman, aged 43-48, had been well all her life and at regular work, but was getting more disabled. Operation was refused and she has improved symptomatically during the next five years and resumed work, but the heart is getting larger (c.t.r. 58 instead of $55 \%$ ). She has now had catheterization but operation has not been advised in view of her improvement.

Case 9. A man, aged 34-40, was seen because he was anxious to continue flying: he was leading a normal life with only slight dyspnœa but there was some left ventricular strain. Operation was not advised though in retrospect $I$ think this was wrong. He is now in Africa and writes that he is well and has noticed no change in his capacity.

Case 10. A woman, aged 29-35, complained of some dyspnœa but was able to lead a normal life, though her heart was large. Six years later, she was more breathless, the heart was larger (c.t.r. 65 to $68 \%$ ) and there was severe left ventricular strain (Fig. 4). The pulmonary arterial pressure was only slightly raised, 45/35. Operation was advised and during the six months she was waiting she became worse and was glad that she had accepted it. Three months after, she is much better, the pulse pressure is 40 instead of 80 , and the heart is already smaller (c.t.r. 60 instead of $68 \%$ ). 

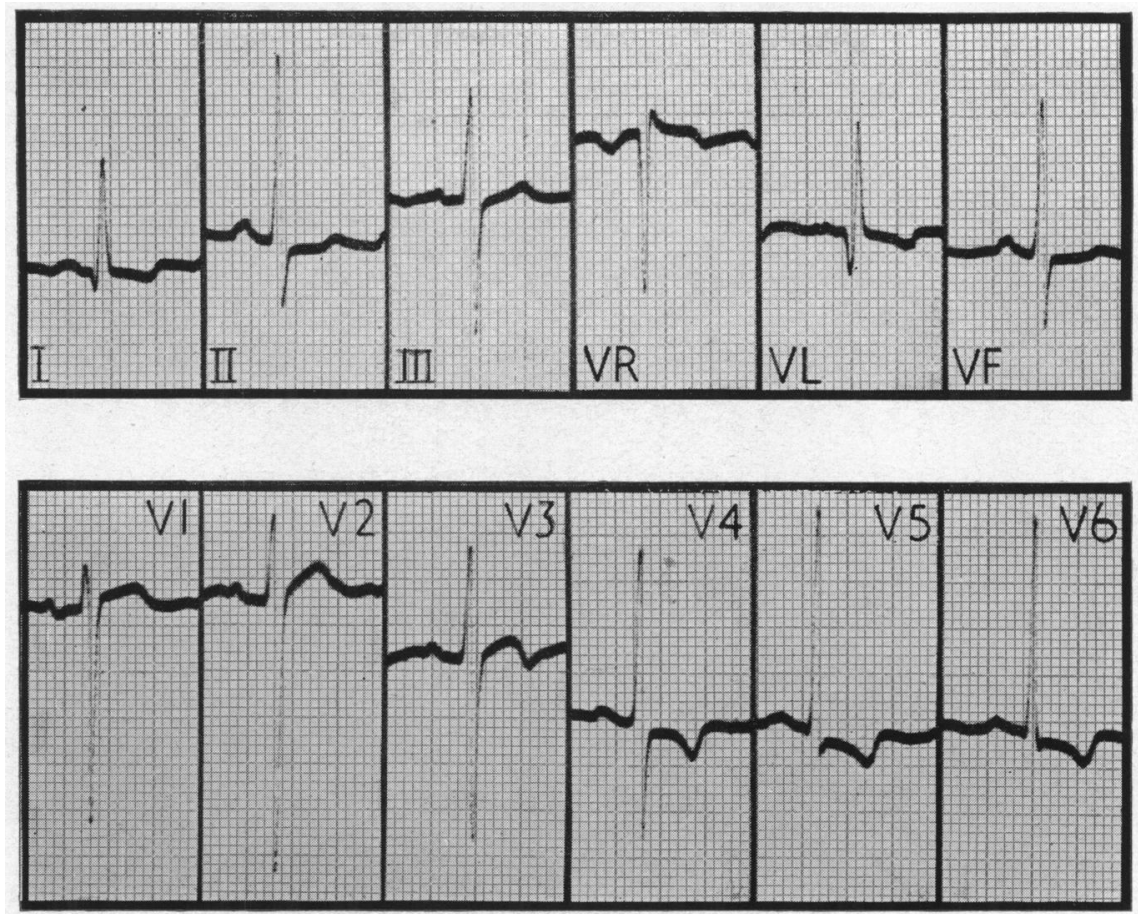

Fig. 4.-Left ventricular preponderance and strain from a woman, aged 35 , with a patent ductus and a large heart. The $T$ waves are biphasic in leads I and V3, and inverted in VL, V4, V5, and V6. The patient has since had a successful operation and there is less LV strain. Case 10.

Case 11. A woman, aged 45, did not notice much dyspnœa though she had a very large heart: generally only a systolic murmur was heard but occasionally a continuous murmur. The pulmonary pressure was $68 / 40$ when the aortic pressure was $130 / 50$ which probably explains why there was generally no murmur during diastole. The ductus was divided by Mr. Brain and the pulmonary arterial pressure fell at once from $57 / 47$ to $39 / 27 \mathrm{~mm}$. Three months later she was more active; the pulse pressure was smaller, the left ventricular strain was less, and her heart was already smaller (c.t.r. 63 instead of $68 \%$ ).

\section{Older Patients Losing Ground}

All the 6 patients in this group had classical continuous murmurs and pulse pressures from 60 to over $100 \mathrm{~mm}$. All except Cases 16 and 17 had left ventricular strain (Fig. 6), sometimes severe. All except Case 13 had large hearts, the cardiothoracic ratio being over 60 per cent in four. All were finding it difficult to carry on their normal activity or were more seriously disabled. Catheterization was performed in five of them and showed that they all had large shunts, but no larger than in most of the other patients, 50 to 65 per cent of the left ventricular output passing through the ductus. The pulmonary arterial pressure was normal in 2 and slightly raised in 3 (see Table IV).

Case 12. An Indian, aged 42, had been increasingly disabled since he was 37 with paroxysmal tachycardia and early left ventricular failure. His heart was large and there was left ventricular strain. He came to this country for catheterization and operation but refused both.

Case 13. A woman, aged 41 , had been very well but was finding her daily work difficult. The pulse pressure was wide, 170/60, and it is surprising that there was no enlargement of her heart (Fig. 5). A year later, she could not manage her work so operation was carried out by Mr. Holmes Sellors. Four years later her condition is excellent and there is less left ventricular strain.

Case 14. A woman, aged 35, developed auricular fibrillation and was hardly able to do anything from the age of 32 years. The heart was large (c.t.r. $68 \%$ ) and the pulse pressure very wide for a patent ductus, about 180/20; the pulmonary arterial mean pressure was $39 \mathrm{~mm}$. She is much better after operation and has lost some of her left ventricular strain. 


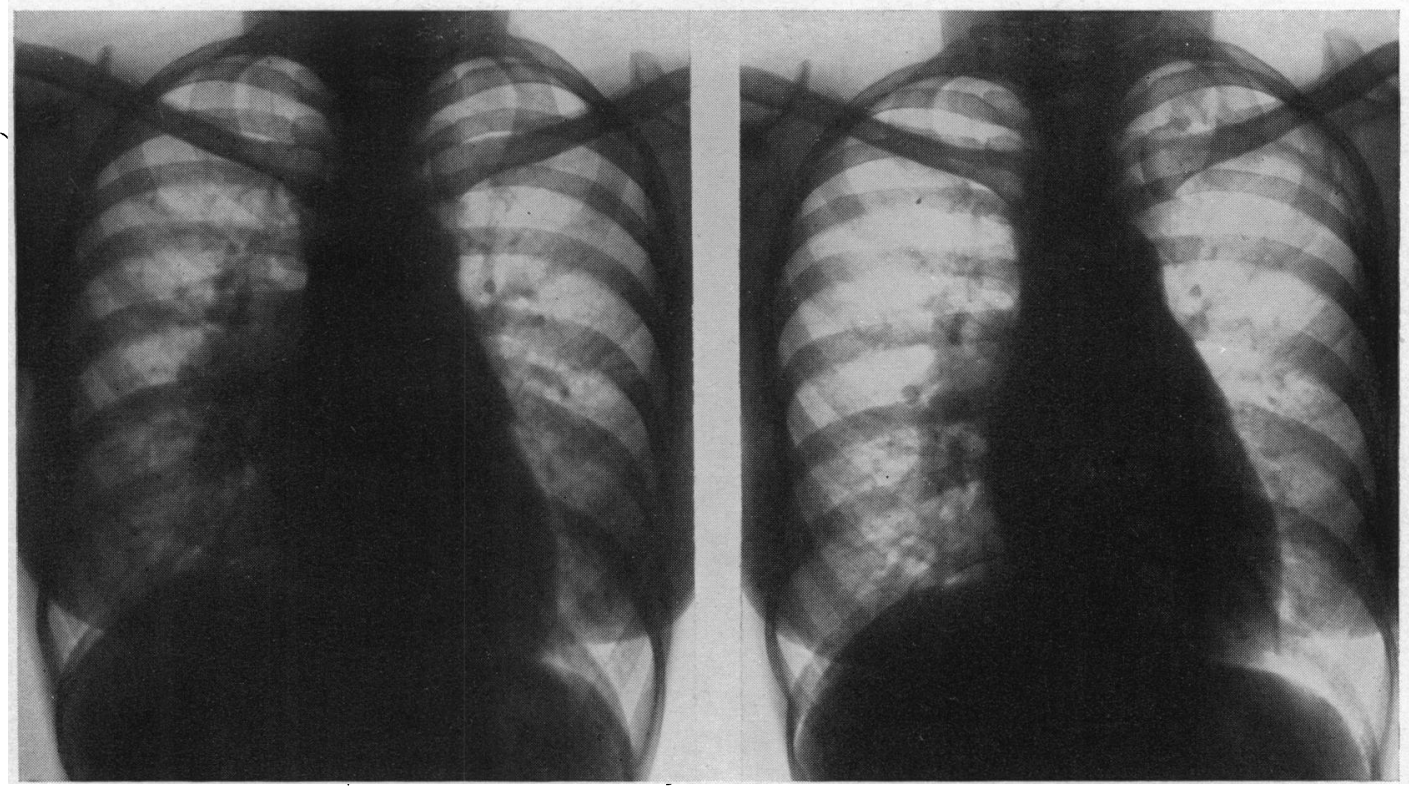

A

B

Fig. 5.-A heart that was normal in size (c.t.r. $50 \%: 11 \cdot 0 / 22.0 \mathrm{~cm}$.) although the patient was 42 years old and had a large shunt through a patent ductus. (A) Before operation, with very pleonæmic lungs. (B) After closure of the ductus, showing less pleonæmic lungs. Case 13.

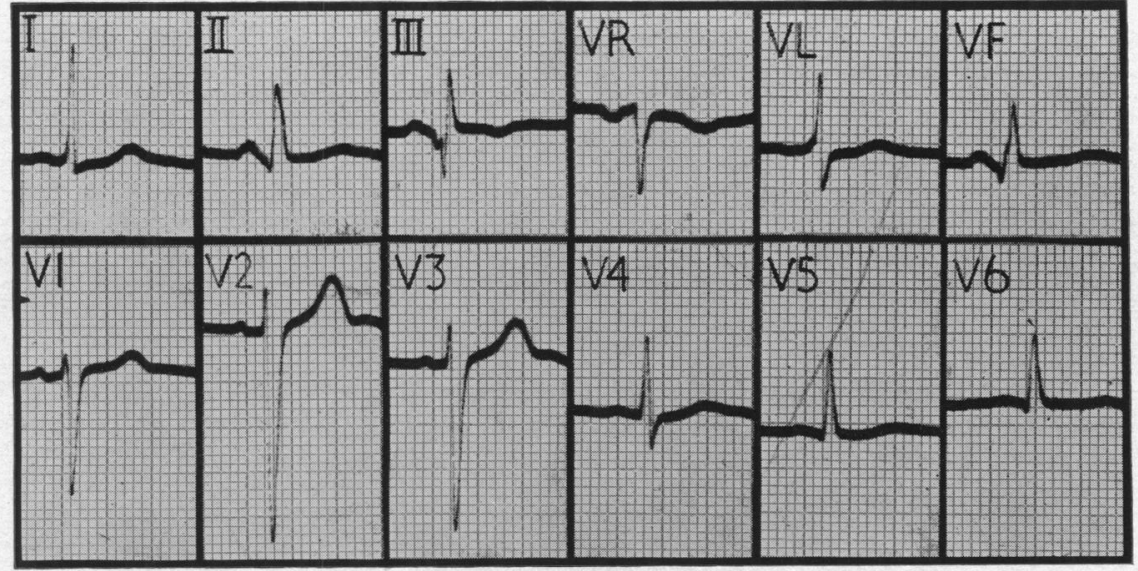

Fig. 6.-Left ventricular preponderance with early signs of strain: the $T$ waves are small or flat in V4, V5, and V6, though they had been upright four years before. From a man, aged 38, with a patent ductus and a large heart, who has since had a successful operation. Three months later, the $T$ waves were again upright in leads V5 and V6. Standardization in chest leads, half normal, $1 \mathrm{Mv} .=0.5 \mathrm{~cm}$. Case 15 . 
Case 15. A man, aged 34-38, had been fairly well when he was first seen but four years later was finding his work difficult. The heart was large and the T waves were now ffat in V4-V6 (Fig. 6) though they had been upright before: the pulmonary arterial pressure was raised, $45 / 25 \mathrm{~mm}$. His ductus has been closed and after three months he feels much better, the pulse pressure is normal, the heart smaller (c.t.r. 50 instead of $54 \%$ ), and the T waves in V4-V6 are again upright.

Case 16. A woman, aged 53, was not allowed to do much as a girl because of her heart but led a normal life afterwards. When she was 48 she became breathless playing golf and was advised to have an operation for her patent ductus. She did nothing about this for five years, by which time she had developed cardiac asthma and slight congestive failure. The heart was very large (c.t.r. $65 \%$ ) and there was left ventricular strain but no rise of pulmonary arterial pressure. A successful operation has been carried out recently.

Case 17. A woman, aged 28-36, had congenital pulmonary stenosis as well as a patent ductus. She had a typical continuous murmur and a large heart (c.t.r. $69 \%$ ), but still led an active life. The high pressure in the right ventricle $(158 / 10 \mathrm{~mm}$.) and the preponderance of this ventricle suggested that it was no use closing the ductus without pulmonary valvotomy, and this seemed too dangerous while she was so well. When she was 36 , however, her increasing disability and heart size were thought to justify the risk, and the ductus was closed and pulmonary valvotomy performed. A year later, she could again lead an active life and the heart was much smaller (c.t.r. from 69 to $55 \%$ ).

\section{Older Patients who have Died}

The three patients who have died illustrate three different dangers: one died from heart failure with a balanced shunt; one died a few days after closure of the ductus nine months after the shunt had become reversed; and the third died suddenly. They provide further evidence that operation should be considered even in older patients whenever an experienced surgeon is available.

Case 18. A woman, aged 39, was admitted with congestive heart failure; she had a large heart and a systolic murmur only and was thought to have an atrial septal defect. After necropsy when the ductus was found patent we were able to trace the hospital where she had been nine years before with pneumonia and she then had a classical continuous murmur. She has been reported (Campbell and Hudson, 1952).

Case 19. A woman, aged 40, had a few symptoms and played tennis up to her marriage at 29 years. She was seen then by Dr. H. D. Heimann of Johannesburg, who found that she had a continuous murmur and a large heart (c.t.r. $57 \%$ ). She had one child and was fairly well until she was 36 , after which she became breathless and began to feel faint on exertion and lost consciousness unless she was careful to stop at once. When she was 39 , any exertion brought on cyanosis that was confined to the lower limbs and the left arm.

At catheterization by Dr. R. H. Goetz in South Africa, the catheter passed through the ductus into the aorta; at rest the pulmonary pressure was sometimes $15 \mathrm{~mm}$. lower than the aortic, but it was sometimes higher, as presumably it always was on exertion. There was a systolic murmur and thrill in the pulmonary area and below this a long loud diastolic murmur and thrill that were thought to be due to pulmonary regurgitation; this was confirmed by its persistance after the ductus was closed. Her heart (c.t.r. $60 \%$ ) and the pulmonary arteries had become even larger (Fig. 7). The cardiogram showed mainly left ventricular strain but an R wave of $10 \mathrm{~mm}$. in VI showed right ventricular hypertrophy also-(Fig. 8). Her hæmoglobin was 120 per cent.

She was seen nine months after the first reversal of her shunt and was getting worse, so the ductus was closed by Sir Russell Brock. The aorta and pulmonary artery were both very large, and the ductus was calcified and $25 \mathrm{~mm}$. in diameter at the aortic end. The pressures were very low during operation but closing the ductus with the finger increased the pulmonary arterial pressure to $70 / 48$ against $37 / 29$ in the aorta, compared with $37 / 35$ and $45 / 35$ respectively just before. Her condition was never good and auricular fibrillation started two days later and was difficult to control. The next day she died suddenly. There was no necropsy.

Case 20. A woman, aged 32-38, was somewhat breathless but led a normal quiet life with sedentary work. The extreme carotid pulsation and water hammer pulse with a blood pressure 200/20-50 suggested aortic incompetence and were much more than is usual with a ductus, but the murmur and its site were typical. She was advised to have an operation but refused.

Six years later, when she was 38 , she wrote that she was getting on well though troubled by frequent paroxysms of tachycardia that were reduced in frequency by quinidine. Some weeks later she was admitted because of a longer paroxysm which was finally stopped with procaine amide. The physical signs and the wide pulse pressure were much the same and the heart was no larger (c.t.r. $64 \%$ ) but there was more left ventricular strain. It was, in fact, surprising that she had done as well for so long. She again refused operation and was due to go home. One night she had a paroxysm at a rate of 160 for fourteen hours: she seemed as usual the next morning, ate her lunch without complaint, and started to get out of bed when she fell back dead. There had been some small spikes of temperature during the last ten days. 


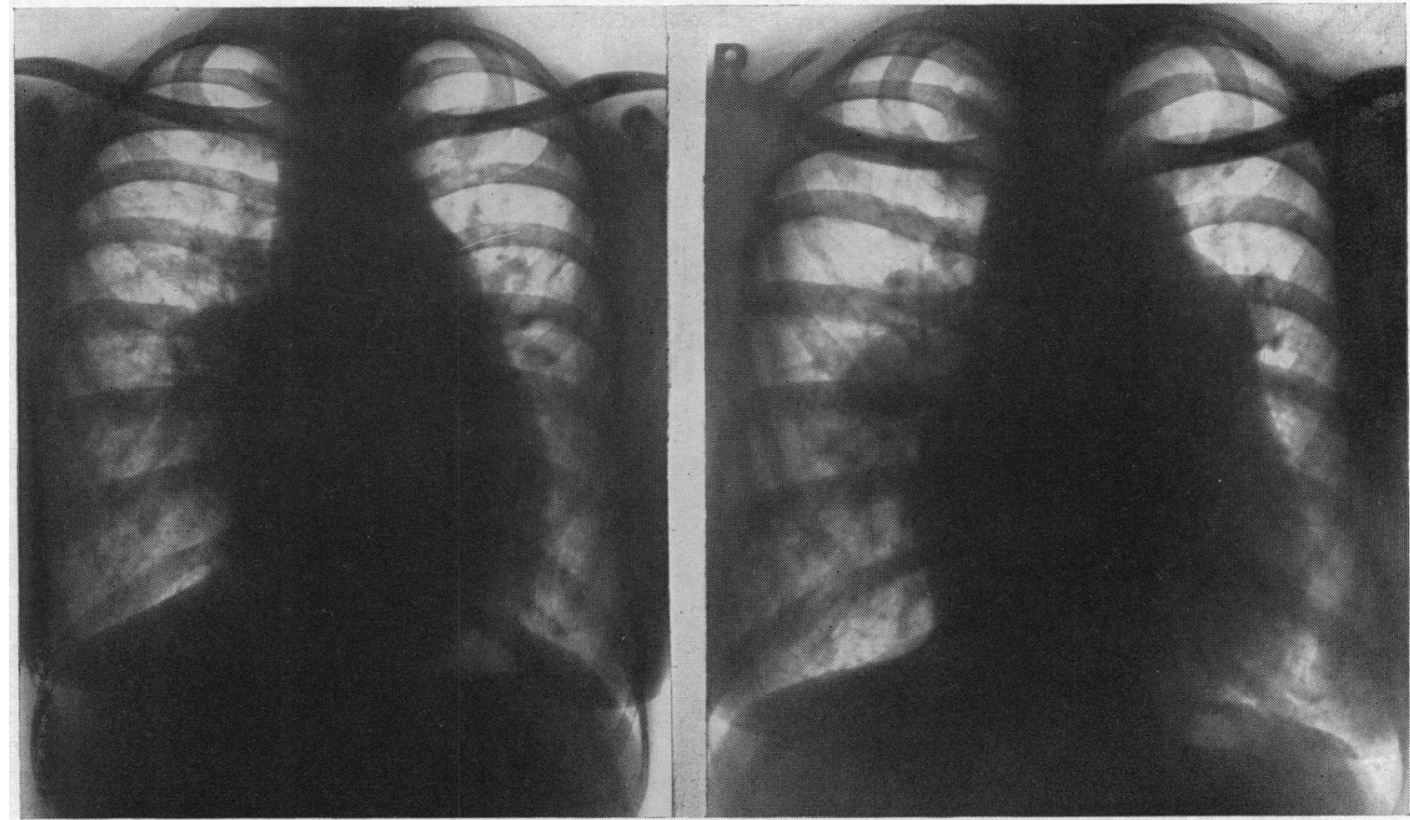

A

B

Fig. 7.-(A) A large heart (c.t.r. $57 \%: 12.9 / 22.6 \mathrm{~cm}$.) from a patient with a patent ductus and only moderate symptoms. (B) From the same patient ten years later showing a larger heart (c.t.r. $60 \%: 14 \cdot 1 / 23 \cdot 4 \mathrm{~cm}$.) and still larger pulmonary arteries about nine months after the flow through her ductus had become reversed. Case 19.
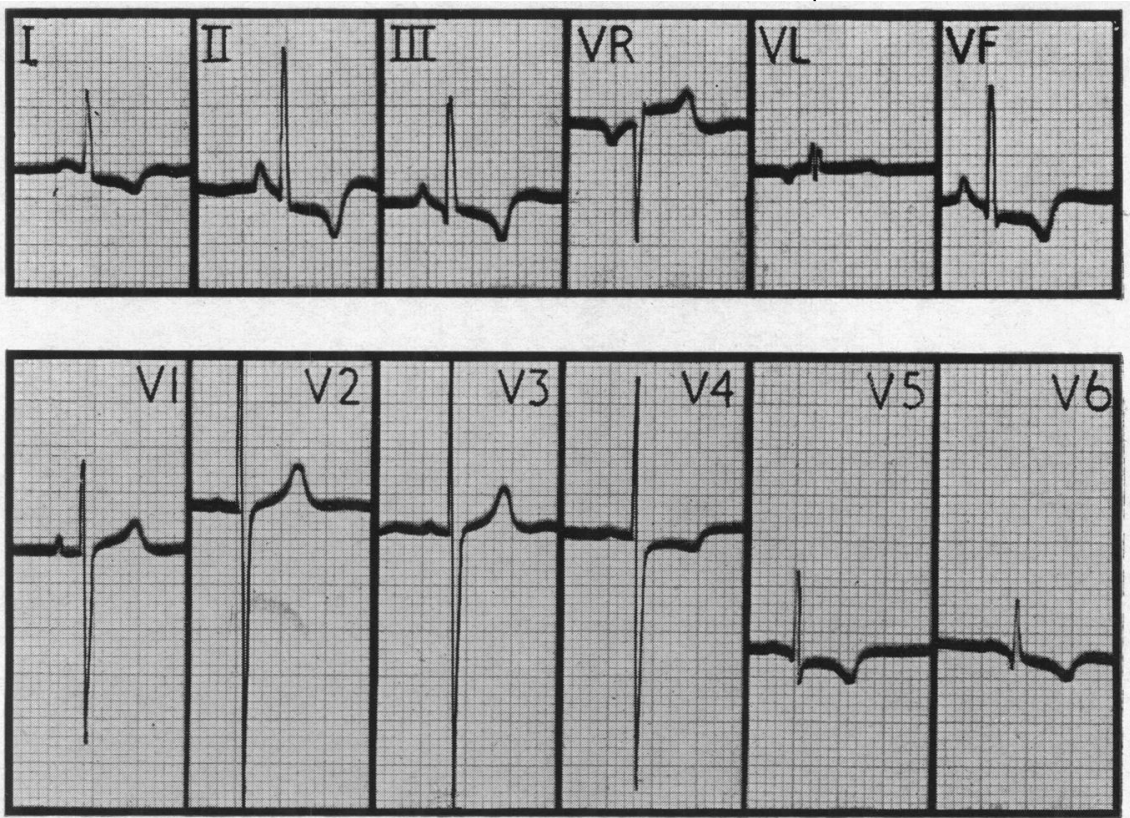

Fig. 8.-Biventricular hypertrophy in the electrocardiogram. There are relatively large $\mathbf{R}$ waves in V1. Although the pulmonary arterial pressure had risen high enough to reverse her shunt through the ductus for nine months, there is more evidence of strain on the left ventricle which had probably been progressive for 40 years while the strain on the right ventricle was more recent. Standardization, in chest leads, half normal; $1 \mathrm{Mv} .=0.5 \mathrm{~cm}$. Case 19 . 
Necropsy. The heart weighed $600 \mathrm{~g}$. The right ventricle was hypertrophied to $7 \mathrm{~mm}$. and the left to $17 \mathrm{~mm}$. The pulmonary valve ring measured $77 \mathrm{~mm}$., and the pulmonary trunk and main branches were thin-walled and dilated. The aortic vale ring measured $65 \mathrm{~mm}$. and the cusps were thickened; just below there were the renants of a sub-aortic fibrous band but no stenosis (Fig. 9). The aorta showed minimal atheorma. The ductus was patent, and its aortic orifice was bowl-shaped and $15 \mathrm{~mm}$. wide, while it was only 10 by $5 \mathrm{~mm}$. at the pulmonary end. Just below the pulmonary orifice was a flat mural thrombus about $15 \mathrm{~mm}$. by $5 \mathrm{~mm}$.: this did not look infected but proved to be so, and thus infective endoarteritis was probably the cause of her more frequent paroxysms and indirectly of her death.

On histological examination there was congestion of the capillaries of the lungs and light cellular exudate in the alveoli. No emboli were found in the lungs and the vessels were within normal limits. There was, therefore, no confirmation of pulmonary hypertension though the hypertrophy of the right ventricle suggested that it might have started.

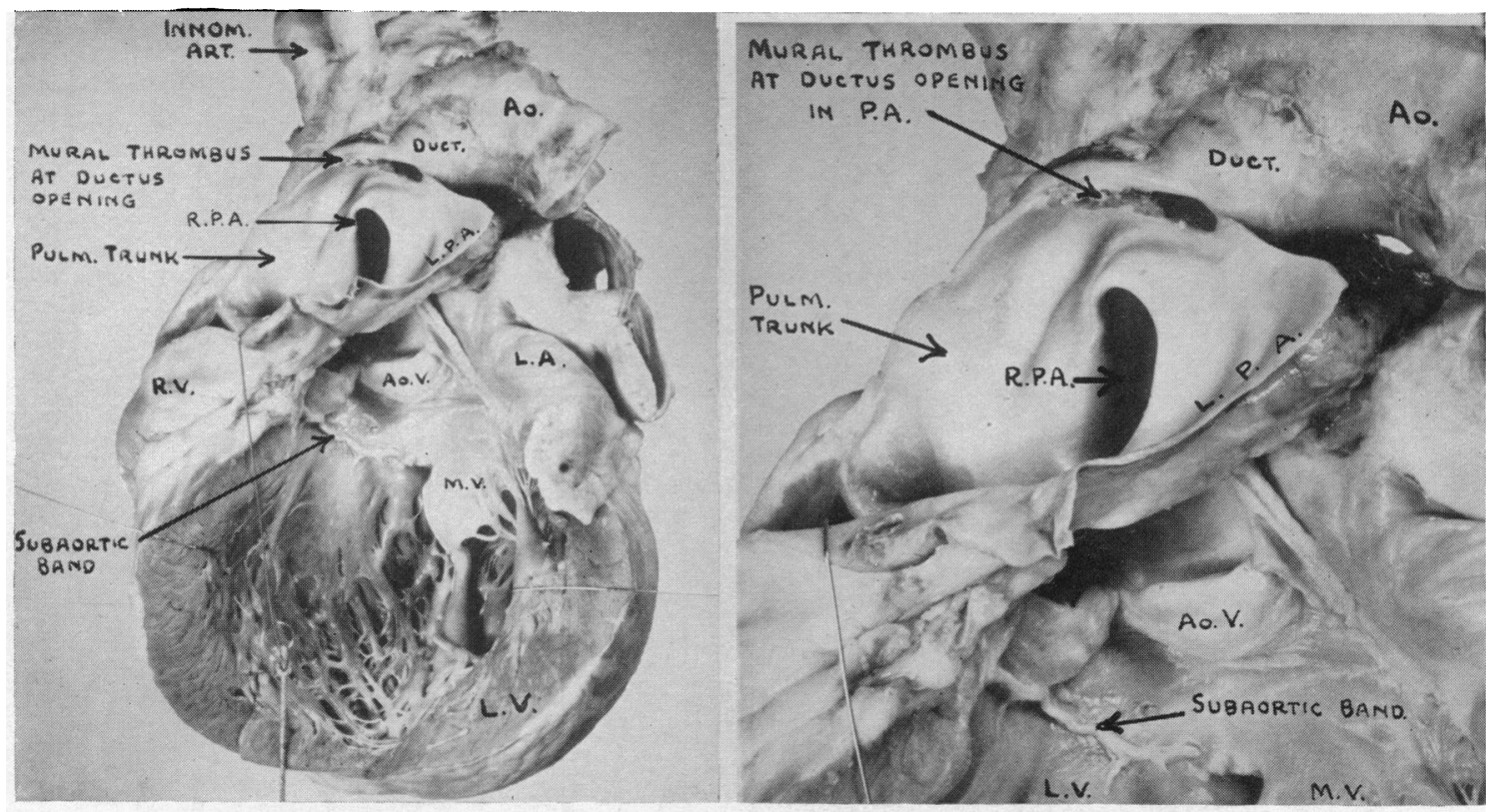

FIG. 9.-The heart opened to show the very large left ventricle. The large bowl-shaped patent ductus arteriosus is seen, and at its lower opening into the left pulmonary artery there is a rather flat mural thrombus. Below the aortic valve the remains of a sub-aortic fibrous band is clearly seen, but it was not causing any stenosis. Ao=Aorta, Ao. $\mathrm{V}=$ Aortic valve, and $\mathrm{MV}=$ Mitral valve. Case 20.

\section{Some Younger Patients}

Nine patients between 25 and 34 will be referred to shortly. Three of them were well and seemed likely to continue so, but are being seen again to reconsider surgical treatment. Two others, aged 25 and 30, had operations on general principles although they were not losing ground. In the former, the continuous murmur was quite typical, but had not developed when she was eight years old: I had made notes that no murmur could be heard in diastole in any position or after exercise and had not, therefore, made the correct diagnosis.

The other four provide some support for the view that a patent ductus should always be closed.

Case 21. A man, aged 27, had been in the army but afterwards found his work as a decorator getting more difficult. Operation was carried out successfully.

Case 22. A man, aged 26, had been losing ground for two years with frequent paroxysms of tachycardia: his heart was large and his pulmonary arterial pressure had risen to $78 / 54$, so that the murmur might not have remained a continuous one much longer. There was some left ventricular strain and also some right ventricular hypertrophy, $\mathrm{R}$ in V3R being as large as $\mathrm{S}$ (Fig. 10). He has been well since operation. 

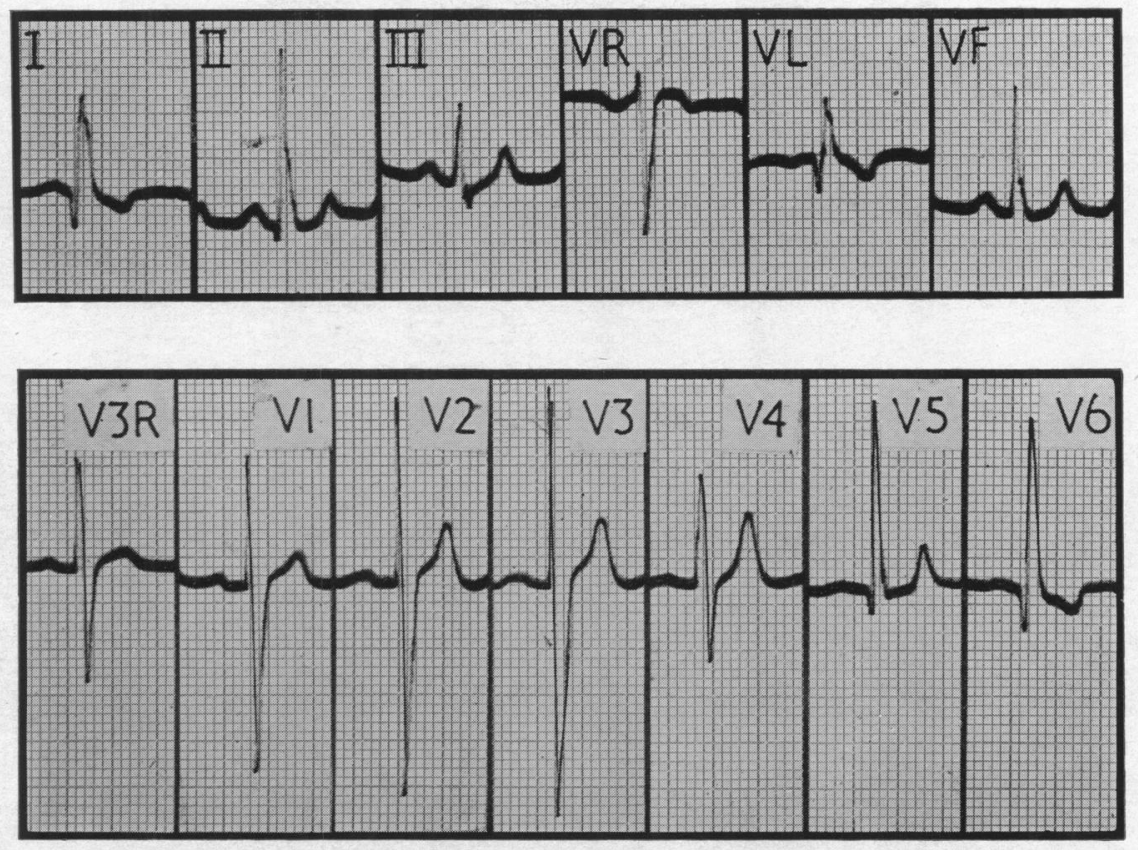

FIG. 10.-Biventricular hypertrophy in the electrocardiogram from a man, aged 26, who has since had a successful operation. There is some left ventricular strain, as $T$ is inverted in leads I and V6. He had pulmonary hypertension $(78 / 54 \mathrm{~mm}$.) and the $R$ waves in V3R and V1 suggest some right ventricular hypertrophy as well. Standardization in the chest leads, half normal, $1 \mathrm{Mv} .=0.5 \mathrm{~cm}$. Case 22 .

Case 23. A girl, aged 26, had to give up her work as a teacher. After an operation elsewhere the ductus recanalized and she could do very little. There was a typical continuous murmur and thrill, a loud pulmonary second sound, a pulmonary arterial pressure of $65 / 39$, and a large heart (c.t.r. $59 \%$ ) with some hypertrophy of both ventricles on radioscopy and in the cardiogram (Fig. 11).

A further difficult operation under hypothermia was thought to be her only chance. She seemed to be recovering but died the next morning with a nodal tachycardia (190 a minute). In addition to the very large pulmonary artery and ductus there was a small aneurysm of the aorta. Necropsy showed that the ductus had been closed; there was also coarctation of the aorta, the lumen being rather less than $1 \mathrm{~cm}$. There were at least two areas of softening, about $1 \mathrm{~cm}$. in diameter, in the internal capsule. We have no information about the condition of the smaller pulmonary arteries.

Case 24. A woman, aged 30, had always been a little short of breath but managed most of her housework. She had a collapsing pulse, a blood pressure of $155 / 59$, and a very loud continuous murmur and thrill, perhaps with an independent diastolic murmur at the base. On catheterization there was a rise of $\mathrm{O}_{2}$ saturation from 63 in the right atrium to 80 per cent in the right ventricle. The most likely diagnosis seemed a patent ductus with pulmonary regurgitation but a ventricular septal defect with aortic regurgitation could not be excluded. Operation was not advised as she was then pregnant for the second time: her confinement was normal. Three years later she was reasonably well and the physical signs were unchanged. Nothing was found that was incompatible with the diagnosis of patent ductus and in view of the large heart (c.t.r. $66 \%$ ) operation has been advised.

There are, of course, patients even under 20 who show the urgent need for operation. A girl, aged 13, was fairly well until she developed bacterial endocarditis; during this illness the heart became larger and the blood pressure widened. There was gross left ventricular strain with $T$ inversion from V4 to V6. The ductus was $15 \mathrm{~mm}$. wide and rather fragile but was successfully closed. Some months later, her blood pressure was $110 / 70$ instead of $135 / 30$ and the heart was smaller (c.t.r. 55 instead of $67 \%$ ).

Another girl, aged 14, was seriously disabled and had a large heart (c.t.r. 65\%). There was such 

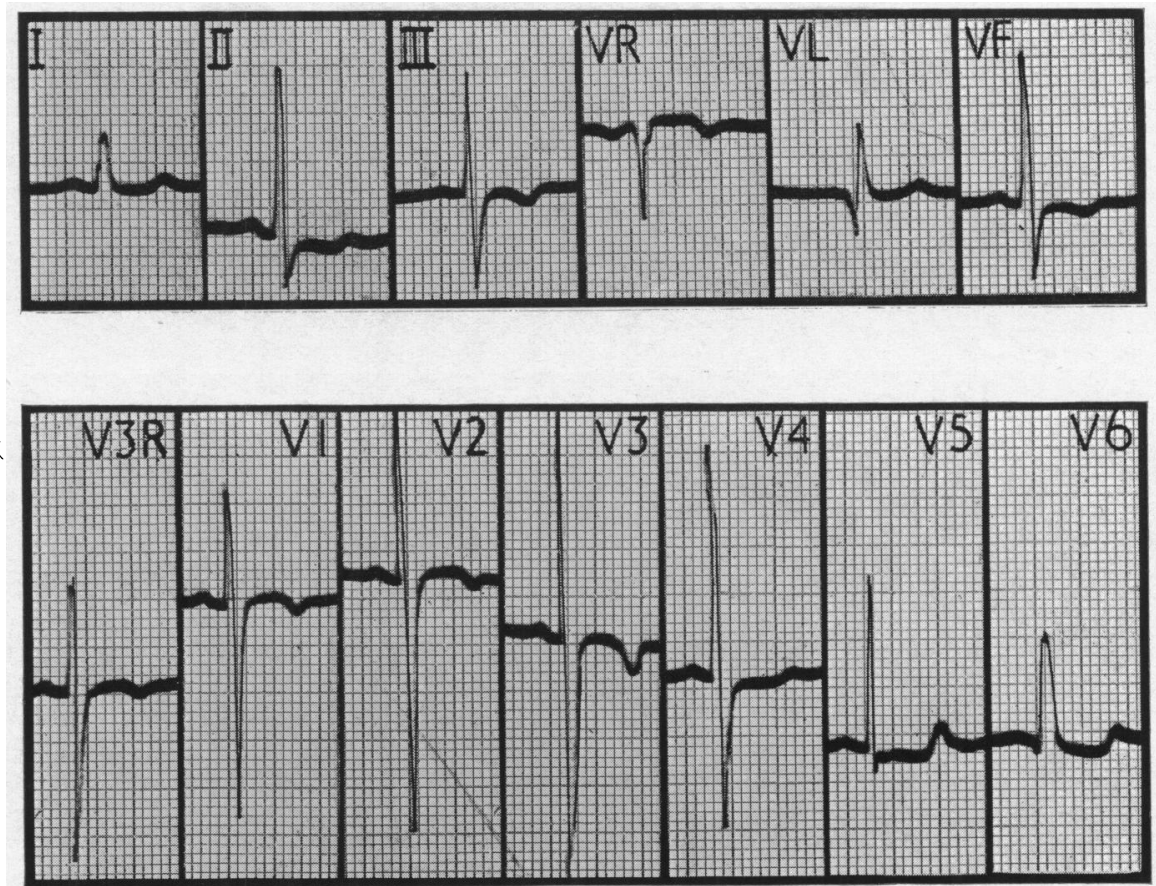

FIG. 11.-Biventricular hypertrophy from a woman, aged 26, with a large heart and increasing disability, where the ductus had been tied but had recanalized and left her with increasing symptoms. There are large $R$ waves in V3R and V1, and the $T$ waves are small or inverted in most leads. Standardization normal. Case 23.

striking pulsation that aortic incompetence was suspected, though the murmur was classical and catheterization confirmed the diagnosis, with a shunt that was 55 per cent of the left ventricular output: the pressure in the pulmonary artery was $60 / 46$. When the ductus closed at operation it fell from $50 / 40$ to $30 / 20$, and at the same time, the pressure in the aorta rose from $60 / 44$ to $104 / 68$. She made a good recovery.

The progress of many of these patients can not be regarded as satisfactory and reinforces the argument that most patients with a patent ductus should have it closed while they are young. The question is dealt with more fully in the discussion.

\section{Pulmonary Hypertension in Young Patients}

In the older patients discussed so far the pulmonary arterial pressure was often normal and often somewhat raised. It can be very high even in young children and we have seen three girls between the ages of 3 and 6 years with systolic pressures between 70 and $87 \mathrm{~mm}$. Hg. All three had classical continuous murmurs though this had not been recognized in the third where the quieter diastolic part and the loud split second sound made it difficult for some people to hear. This was probably due to the trivial aortic-pulmonary gradient during diastole (see Case 27) and soon she might have had a systolic murmur only. Two of the three had suffered since infancy from frequent " bronchitis" with asthma and pulmonary congestion-episodes that are very common with the larger left-to-right shunts. All had hypertrophy of the left ventricle and two some of the right ventricle also. The systemic flows averaged 4.2 and the pulmonary flows 11.8 litres a minute, which means that two-thirds of the left ventricular output was passing through the ductus, but this is no more than in many patients with a normal pulmonary pressure. All three have had successful operations and are much better and almost free from their bronchial attacks: the heart and the pulse pressure are smaller and the pulmonary arterial pressure has fallen to normal (Table V). 
TABLE V

Reduction of High Pulmonary Arterial Pressures after Operation

\begin{tabular}{|c|c|c|c|c|c|c|c|c|c|c|}
\hline \multirow{2}{*}{$\begin{array}{l}\text { Case } \\
\text { No. }\end{array}$} & \multirow{2}{*}{$\begin{array}{l}\text { Sex } \\
\text { and } \\
\text { age }\end{array}$} & \multirow{2}{*}{$\begin{array}{c}\text { Shunt as } \\
\text { percentage } \\
\text { of LV output } \\
(\%)\end{array}$} & \multicolumn{2}{|c|}{$\begin{array}{l}\text { Heart size } \\
\text { (c.t.r. }(\%))\end{array}$} & \multicolumn{2}{|c|}{$\begin{array}{l}\text { Systemic blood } \\
\text { pressure }\end{array}$} & \multicolumn{2}{|c|}{$\begin{array}{c}\text { Pulmonary aterial } \\
\text { pressure }\end{array}$} & \multicolumn{2}{|c|}{$\begin{array}{l}\text { Pulmonary flow } \\
\text { (litres/min.) }\end{array}$} \\
\hline & & & Before & After & Before & After & Before & After & Before & After \\
\hline $\begin{array}{l}25 \\
26 \\
27\end{array}$ & $\begin{array}{l}\text { F6 } \\
\text { F3 } \\
\text { F5 }\end{array}$ & $\begin{array}{l}66 \\
70 \\
54\end{array}$ & $\begin{array}{l}59 \\
65 \\
60\end{array}$ & $\begin{array}{l}51 \\
53 \\
55\end{array}$ & $\begin{array}{l}100 / 50 \\
136 / 46 \\
110 / 55\end{array}$ & $\begin{array}{l}110 / 80 \\
125 / 85 \\
100 / 70\end{array}$ & $\begin{array}{l}87 / 50 \\
71 / 31 \\
73 / 46\end{array}$ & $\begin{array}{l}22 / 6 \\
18 / 9 \\
30 / 19\end{array}$ & $\begin{array}{r}14.5 \\
9.6 \\
11 \cdot 2\end{array}$ & $\begin{array}{l}6.0 \\
3.0 \\
3.6\end{array}$ \\
\hline
\end{tabular}

Case 25. A girl, aged 6, was dyspnœic and had a continuous murmur, a loud pulmonary second sound, a large heart, and probably some right as well as left ventricular hypertrophy. Catheterization showed the pulmonary arterial pressure was $87 / 50$ which was not much below the aortic pressure at that time, $100 / 50 \mathrm{~mm}$. Nine months after a successful operation she was extremely fit: the pulmonary arterial pressure was $20 / 6$ instead of $87 / 50 \mathrm{~mm}$.

Case 26. A girl, aged 3, was very short of breath and had attacks like asthma since infancy. There was a continuous murmur, a loud pulmonary second sound, a large heart, and left ventricular preponderance. Nine months after the ductus had been closed she was very well and had kept without her respiratory infections: the pulmonary arterial pressure had fallen from $71 / 31$ to $18 / 9 \mathrm{~mm}$.

Case 27. A girl, aged 5, had often been in hospital with respiratory infections and pulmonary congestion, and was sent up as a case of atrial septal defect. She had a large heart and a continuous murmur which had not been recognized; $R$ waves of about $8 \mathrm{~mm}$. in V1 and of $7 \mathrm{~mm}$. in V6 suggested hypertrophy of both ventricles. The pressure was 73/46 in the pulmonary artery at a time when it was only 85/47 in the aorta; five months after operation it had fallen to $30 / 19 \mathrm{~mm}$.

These patients show that a high pulmonary pressure in young children is completely reversible, even when it is very high and not much below the systemic pressure (see discussion).

\section{Patients with a Balanced or Reversed Shunt from Infancy}

Several of the patients already described have had a high pulmonary arterial pressure, in one high enough to reverse the shunt through the ductus after it had been in the normal direction for many years. There is, however, another group where it has been high enough from infancy or from an early age to produce a balanced or even a reversed shunt all the time. We have seen 6 such patients during the time that we have seen the 160 with the ordinary form of patent ductus.

All six showed physical signs of pulmonary hypertension, and this was confirmed by direct measurement (see Table VI): we think that the pressure had been raised since early infancy. Except for Case 28, none had evidence of a left-to-right shunt. These were the only patients in whom the pulmonary resistance was greatly increased, though it was somewhat increased in a few others. All six had right ventricular preponderance, and sometimes strain, while in the others hypertrophy of the left ventricle was the rule and hypertrophy of both ventricles was the most that was seen when the pressure rose. There was no general enlargement of the heart such as is common in complicated patent ductus, but this was not true of Case 31. All these patients showed polycythæmia and an increased hæmoglobin percentage, except Case 28 where we think that the shunt was balanced and Case 32 who was anæmic.

In the last four of these six the shunt was reversed, and the patient therefore showed cyanosis in the lower parts of the body and generally less cyanosis or none at all in the upper parts. In the first and perhaps in the second the shunt was generally balanced, and the diagnosis was made only after catheterization or angiocardiography. Although we think that Case 28 never had a continuous murmur and that her pulmonary hypertension dated from infancy, she should perhaps be included with the earlier patients as when she was 18 there was still a large left-to-right shunt through the ductus and no cyanosis was noted. Some months later when she was in Guy's Hospital the shunt was thought to be balanced but she was not recatheterized: the $\mathrm{O}_{2}$ saturation was then 91 per cent 
TABLE VI

Some Physiological Data in Patients with a Balanced or Reversed Shunt

\begin{tabular}{|c|c|c|c|c|c|c|c|c|c|c|c|c|}
\hline \multirow{2}{*}{$\begin{array}{l}\text { Case } \\
\text { No. }\end{array}$} & \multirow{2}{*}{$\begin{array}{l}\text { Sex } \\
\text { and } \\
\text { age }\end{array}$} & \multirow[b]{2}{*}{$\begin{array}{l}\text { Heart } \\
\text { size } \\
\text { (c.t.r.) } \\
(\%)\end{array}$} & \multirow[b]{2}{*}{$\begin{array}{l}\mathrm{Hb} \text {. } \\
(\%)\end{array}$} & \multicolumn{4}{|c|}{$\mathrm{O}_{2}:$ percentages } & \multicolumn{3}{|c|}{ Pressures } & \multirow{2}{*}{$\begin{array}{c}\text { Flows } \\
\text { (litres/ } \\
\text { sq.m./ } \\
\text { min.) } \\
\text { Syst. Pulm. }\end{array}$} & \multirow{2}{*}{$\begin{array}{l}\text { Electrocardio- } \\
\text { gram }\end{array}$} \\
\hline & & & & $\begin{array}{l}\text { RA } \\
\text { RV }\end{array}$ & PA & Brachial & Femoral & RV & PA & $\begin{array}{l}\text { Syst. } \\
\text { art. }\end{array}$ & & \\
\hline $19 *$ & F40 & 60 & 120 & - & - & - & - & - & $110 / 65$ & $125 / 63$ & - & LVS and some \\
\hline $28^{*}$ & F19 & 55 & 84 & 51 & 79 & 91 & 90 & $99 / 7$ & $108 / 72$ & $125 / 75$ & $-\quad-$ & $\begin{array}{l}\text { RVS. T inverted } \\
\text { V1-V4 }\end{array}$ \\
\hline 29 & F16 & 53 & 115 & 69 & 71 & $86 \dagger$ & - & $95 / 0$ & $95 / 65$ & $105 / 80$ & $4 \cdot 2 \quad 2 \cdot 8$ & RVP. $T$ inverted \\
\hline 30 & F38 & 51 & 130 & 55 & 53 & 72 & - & $59 \mathrm{~m}$. & $100 \mathrm{~m}$ & $140 / 10$ & $\begin{array}{ll}? 2.0 & ? 1.5\end{array}$ & $\begin{array}{l}\text { RVS. T inverted } \\
\text { V1-V5 }\end{array}$ \\
\hline 31 & F9 & 57 & 105 & 63 & 68 & 70 & 52 & $120 / 6$ & $120 / 70$ & $120 / 84$ & $-\quad-$ & $\begin{array}{l}\text { RVP. T inverted } \\
\text { V1 }\end{array}$ \\
\hline 32 & F27 & 46 & 89 & 62 & 68 & 96 & 82 & $110 / 5$ & $110 / 63$ & $103 / 57$ & $\begin{array}{ll}1.6 & 1.0\end{array}$ & $\begin{array}{l}\text { RVP. } \\
\text { rising in } \mathrm{V} 2, \mathrm{~V} 3\end{array}$ \\
\hline 33 & M10 & 48 & 135 & 47 & 47 & - & 44 & $66 / 12$ & $66 / 52$ & $66 / 48$ & $-\quad-$ & $\begin{array}{l}\text { RVP. T inverted } \\
\text { V1 }\end{array}$ \\
\hline
\end{tabular}

* Died after operation. $\dagger$ After breathing oxygen, 96 per cent.

in the left brachial and 90 per cent in the femoral artery. She is the only patient in this group where the ductus was closed: when this was done the pulmonary arterial pressure rose from $86 / 76$ to $94 / 77$, but at a second operation four months later it seemed to have fallen as it was 60/30 when the aortic pressure was $96 / 55 \mathrm{~mm}$.

Case 28. A girl, aged 19, had not been allowed to play games but had few symptoms till she was 17 . It was not possible to find out what murmur had been heard when she was 5 but when she was 13 she had a large heart, a basal systolic murmur, and a loud pulmonary second sound, and the consultant made no comment about any continuous murmur so it is unlikely that one had ever been heard. When she was 18, she had the same physical signs and right ventricular strain $(R=S$ in V1 and $T$ inversion from V1 to V4). After catheterization by the late Dr. J. L. Lovibond, operation was advised but Mr. Drew found the ductus so large that nothing was done.

Some months later she was admitted under Sir Russell Brock at Mr. Drew's request. The general condition was the same without any cyanosis clinically. At operation the ductus, $10 \mathrm{~mm}$. long and $24 \mathrm{~mm}$. in diameter at its narrowest part, was closed and she seemed better for some weeks, until she began to have pain in the chest, pyrexia, and hæmoptysis, when X-ray showed an aneurysmal dilatation above the left hilum which gradually increased. At a further operation under hypothermia, a large false aortic aneurysm filled the space between the aortic arch, the bifurcation of the pulmonary trunk, and the medial surface of the left upper lobe. It was dissected and the aorta sutured, but she died with recurrent ventricular fibrillation two hours later (Case 23, Milstein and Brock, 1954). Necropsy confirmed the observations made at operation, but no investigations of the pulmonary blood vessels were made.

Case 29. A girl, aged 14-19, had always been breathless but could walk 4 miles. She became cyanotic in winter but it seemed mainly peripheral. There was a rough systolic murmur, a faint thrill, and a loud and palpable pulmonary second sound, sometimes with a soft pulmonary diastolic murmur. She was thought to have a ventricular septal defect with pulmonary hypertension: most of her cyanosis was pulmonary in origin as the arterial $\mathrm{O}_{2}$ saturation rose from 86 to 96 per cent. A small reversed shunt through the ductus was seen during angiocardiography though it had not been suspected clinically. Her condition has not changed much during five year's observation.

In the next four patients the shunt through the ductus was reversed, though it was not correctly diagnosed in the first till necropsy. No operation for closing the ductus has been advised as it was thought that their pulmonary hypertension dated from infancy and would prove irreversible, and 
in others the disability did not seem great enough to justify operation with such a doubtful chance of improvement.

Case 30. A woman, aged 32-40, had cyanosis from birth and pulmonary hypertension and was thought to have Eisenmenger's complex with pulmonary regurgitation. When she died, however, necropsy showed that the ventricular septum was closed and that the right-to-left shunt was through the ductus from pulmonary artery to aorta. She has been fully reported (Campbell and Hudson, 1951).

Case 31. A girl, aged 9-11, was breathless but not much disabled. Her heart was enlarged and the cyanosis of her feet was enough for her mother to have noticed that it was present here but not in her hands. She has been fully reported by Cosh (1953: his Case 2).

Case 32. A woman, aged 27, had always been breathless but had been getting worse with recurrent hæmoptysis for five years, and had not been able to work for two years. She had always had some cyanosis on exertion and this was worse in the legs and feet than in the hands: there was slight clubbing of the toes but not of the fingers. There was a soft systolic murmur and a loud split second sound in the pulmonary area. The heart was not enlarged but the pulmonary arc was prominent. There was no evidence of a continuous murmur earlier though she had often attended hospital, the last time six years before for toxæmia of pregnancy. The arterial $\mathrm{O}_{2}$ saturation was 96 in the brachial artery and 82 per cent in the descending aorta so there was a fairly large reversed shunt through the ductus.

Case 33. A boy, aged 10-12, had been cyanosed since he was a year old, and suffered from frequent chest infections. He could walk a quarter of a mile slowly, and cyanosis which had become worse recently was more obvious in the legs and feet. A diagnosis of mitral stenosis was made at an early age. There were loud presystolic and mid-diastolic murmurs in the mitral area, confirmed by phonocardiography, and a systolic murmur in the pulmonary area, where the second sound was loud and closely split. The left atrium was dilated and there was right ventricular preponderance with large pointed $\mathbf{P}$ waves in lead II. The reversed shunt through the ductus was confirmed by angiocardiography (Fig. 12) though the pressures

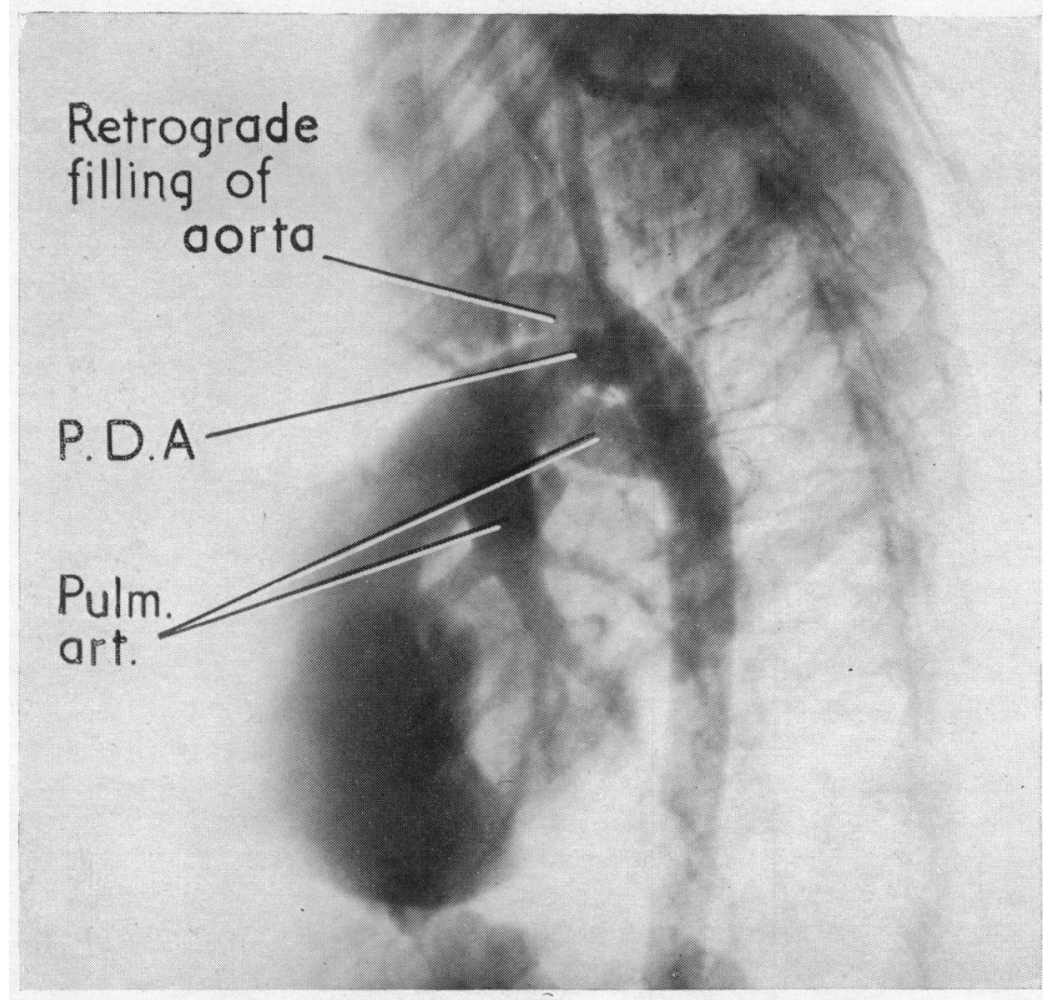

Fig. 12.-Angiocardiogram showing a reversed flow through the ductus with some retrograde filling of the aorta. Both pulmonary arteries are well filled. Case 33. 
in the pulmonary artery and aorta were generally the same. The catheter provided no evidence of any left-to-right shunt and passed from the left pulmonary artery into the descending aorta.

His symptoms seemed to be mainly due to his congenital mitral stenosis. At operation the mitral valve itself was severely stenosed $(3 \mathrm{~mm}$. in diameter) and was made wider with an immediate fall in the left atrial pressure; there was also some narrowing of the subvalvular ring. In the two years since, he has been better and almost free from his winter coughs, but the shunt through the ductus is still reversed.

\section{Discussion}

\section{Prognosis of Older Patients}

This series shows that some patients are still doing well after 35 years but many are not. The first four (Cases 1-4) are without symptoms or any signs to suggest they are likely to get worse; in the first two the ductus is almost closed. Case 5 is 62 and was well until she was 50 but now has some dyspnœa, a large heart, and left ventricular strain. Case 7 had a large heart and Case 9 had left ventricular strain but neither has got worse in the subsequent four years and both are working without symptoms. These seven can be regarded as satisfactory and operation has not been advised in any of them though we think it should have been in Case 9.

Operation was advised but not accepted in four patients. The progress of the first two has not yet proved that it was needed though we still think it would have been wiser: in the other two there can be no doubt of the need. Case 6 was advised to have the ductus closed after her recovery from bacterial endocarditis because of her large heart, but she refused and has got on well for six years without any further increase of heart size. Case 8 has improved symptomatically over the four subsequent years but her heart has got larger (55 to $58 \%$ ). Case 12 could do very little and has continued much the same. Case 20 got on fairly well for six years after operation was advised but then died with paroxysmal tachycardia and bacterial endocarditis. Paroxysmal tachycardia occurred in three patients who were doing badly and it seems, therefore, that it may be more serious prognostically than it usually is.

One patient died with a balanced shunt, the ductus not being recognized (Case 18). The other eight were becoming incapacitated and have had operations: all have been successful except the one in whom the shunt had become reversed (Case 19). Cases 10, 15, and 17 had been under observation for from four to seven years before this and were finding their ordinary days work increasingly difficult-a state of affairs that is well described by Gross (1952) in several middle-aged patientssometimes with a progressive increase in the size of the heart or in the signs of left ventricular strain, though even at this stage the downhill course is often slow and further enlargement of the heart very gradual. Case 11 had a very large heart and left ventricular strain and was losing her continuous murmur from a rising pulmonary arterial pressure. Case 13 could no longer manage her work although the heart was not enlarged. Case 14 was quite incapacitated and had a very large heart. Case 16 had developed left ventricular failure and though she responded well to medical treatment it seemed unlikely that this would last long. In Case 19 the shunt had been reversed for nine months.

There does not seem to be any one indication for operation in middle-aged patients but progressive symptoms, a large heart, or increasing left ventricular strain, or all of these may show the need for operation. Some patients who developed these changes in the third decade (Cases 21-24) or even earlier have been described and reinforce the argument for early operation.

One can hardly read these cases and feel satisfied with the natural prognosis although most patients do well for so many years. It is true that this series is overweighted with those who are doing badly because they are more likely to come for advice, while those who are doing well are only seen by chance. To get a fairer impression the earlier patients should be multiplied several times and some of the later ones should be omitted because they were sent to us from outside the normal Guy's area, e.g. Cases 12 and 22 from India, Case 19 from South Africa when her shunt became reversed, and Case 23 because the ductus had recanalized. But even if these were omitted -and the others were all seen in routine hospital or private work-enough patients deteriorate 
seriously during the third or fourth decades to suggest that all should have the ductus closed while they are young, when it can be done with a small risk.

The problem of a safe operation seems to me crucial. Most younger patients are so well that they will notice little improvement after operation: to their parents they appear normal children and they have an excellent prognosis for the next ten or twenty years. Many people are more interested in the near than in the distant future and this-not unreasonable-point of view can only be overcome by an operative mortality that is almost negligible.

\section{PULMONARY HYPERTENSION}

The pulmonary arterial pressure is high in some patients with patent ductus but not in the majority (Dexter et al., 1947). The reason is not obvious, for some may show a great increase within a few years (Cases 25-27), while others may show none though there has been a large flow through the ductus for 50 years (Cases 3 and 16). Thus Stortein et al. (1952) reported the case of a woman, aged 72 , where the pulmonary pressure was only $44 / 22 \mathrm{~mm}$. and our two oldest patients, aged 62 and 53, still had normal pulmonary pressures, 23/10 and 26/16: perhaps they reached this age because the flow through the ductus was not as large as some but it was 50 per cent of the left ventricular output. Some of these patients with large shunts who reach a good age without pulmonary hypertension develop left ventricular failure. This is supported by the pathological work of Welch and Kinney (1948) who found no increase of vascular sclerosis in 25 patients with large ductuses.

It is interesting to compare the frequency of a raised pulmonary arterial pressure at various ages. Shephard (1954) discussing the pressure-flow relationship in patent ductus found that of 20 patients under 25 years of age the pressure was normal (under $30 \mathrm{~mm}$.) in 11 and increased in 9, the highest systolic pressures being between 50 and 60 in three children of 5 or under. Including these, we now have available figures for 54 patients. There were several where the systolic pressure was just over $30 \mathrm{~mm}$. so we have included those up to $33 \mathrm{~mm}$. with the normals (Table VII). The pressure was

TABLE VII

The Influence of Age on the Pulmonary Arterial Systolic Pressure

\begin{tabular}{|c|c|c|c|c|c|}
\hline & \multicolumn{5}{|c|}{ Age in years } \\
\hline & $0-9$ & $10-19$ & $20-34$ & $\begin{array}{l}35 \text { and } \\
\text { over }\end{array}$ & All ages \\
\hline $\begin{array}{l}\text { Normal or nearly so (up to } 33 \mathrm{~mm} \text {.) } \\
36-60 \mathrm{~mm} . \mathrm{Hg} . . \\
\text { 61-110 mm. Hg }\end{array}$ & $\begin{array}{c}16(3)^{*} \\
6 \\
3\end{array}$ & $\begin{array}{c}4(2)^{*} \\
4 \\
1\end{array}$ & $\begin{array}{l}7 \\
0 \\
2\end{array}$ & $\begin{array}{l}5 \\
3 \\
3\end{array}$ & $\begin{array}{r}32 \\
13 \\
9\end{array}$ \\
\hline With reversed shunts from infancy & 1 & 3 & 1 & 1 & 6 \\
\hline
\end{tabular}

* The figures in brackets are the number where the pressure was $31-33 \mathrm{~mm}$.

normal in 20 and raised in 14 of those under twenty years of age and normal in 12 and raised in 8 of those over twenty years of age. In our 15 patients over 25 years of age who had cardiac catheterization, it was normal (up to $30 \mathrm{~mm}$. systolic) in seven, aged 27, 30, 41, 44, 48, 53, and 60 years; moderately increased $(36 / 13,45 / 35$, and $45 / 25 \mathrm{~mm}$.) in three, aged 35,35 , and 38 years; and greatly increased (40 (mean), 65/39, 68/40,78/54, and 110/63) in five, aged 35, 26, 45, 26, and 40 years respectively.

Chávez et al. (1953a) reported 40 cases of patent ductus with pulmonary hypertension, dividing them into three groups according to its degree. (1) Of 14 patients with slight hypertension, 31$60 \mathrm{~mm}$., and typical continuous murmurs, half were children, aged 10 or less. (2) Of 14 with moderate pulmonary hypertension, $61-100 \mathrm{~mm}$., nine were children of 11 or under, but four were 
between 16 and 27: most still had continuous murmurs but four, including two children, had only systolic and diastolic murmurs. Half had electrocardiographic evidence of mixed right and left ventricular hypertrophy. (3) Of 12 patients with more severe hypertension, 101-136 mm., half were children of 10 or under, though four were between 16 and 33; and only one had a continuous murmur though five (including three children) had diastolic murmurs, generally best heard towards the apex. Most showed right ventricular preponderance and generally strain. In four, all under 17 years, the flow was reversed and in three, aged 3,16 , and 33 years, the flow was sometimes reversed and sometimes in the normal direction.

The authors thought that pulmonary hypertension was generally secondary to the patent ductus in adults but, partly because of the frequency with which they found it in children, that it was then of primary and unknown origin. This seems unlikely for the high pressure in children can generally be reversed by closing the ductus (see later) and is therefore caused directly or indirectly by the large pulmonary flow.

Age does not therefore seem to have much influence on the pulmonary arterial pressure. There is certainly no regular increase with age but the pressure may rise and systolic pressures over $60 \mathrm{~mm}$. are found more often in adult patients. The pressure is still normal in more than a third of them and can be very high even in young children.

Pulmonary Arteriolar Resistance. In patients with a patent ductus the pulmonary resistance is generally low but we have found this less constantly than with atrial septal defect in children and this was also the experience of Wood (1950). In uncomplicated cases under 20, it is generally reduced to about the same levels as in atrial septal defect (0.5-1.4 units) but sometimes it is higher and reaches a normal or slightly increased figure. This applies to our three small children with the highest pulmonary pressures (Cases 25 to 27) and though the resistances were not much above normal before operation they have fallen to normal afterwards.

In patients over 20 years of age the actual resistance is distributed in much the same proportions between low, normal, and high (see Table VII), but this is hardly fair for the normal tendency is for it to become lower-240 at 5 years, compared with 120 dynes $/ \mathrm{sec} . / \mathrm{cm}^{5}$. at 20 years (Shephard, 1954) -so that there are a larger proportion with a pulmonary resistance that is normal or raised instead of being reduced: in most patients, however, including Case 3, aged 60, and Case 16, aged 53, it was still low. On the other hand, in Cases 10 and 15 it was normal and in Cases 11 (who was losing the diastolic part of the continuous murmur), 22, and 23, it was above normal but not very much: all these patients, except Case 11, were getting progressive symptoms and operation was advised in all of them. Shephard (1955) found that the pulmonary arteriolar resistance was often increased in adult patients: thus in the patients under twenty it was normal or reduced in 20 and increased in 3 only; on the other hand, in those over twenty, it was normal or reduced in 4 and increased in 5 patients.

The position was entirely different in the patients with a reversed shunt and in all of them the pulmonary resistance was enormously increased up to 15-30 units.

The statement that the pulmonary arteriolar resistance is increased does not, however, explain the problem and only raises another: why the arteriolar resistance should be so variable in different patients. The pulmonary flows are in the same general range in the patients with normal and in those with high pressures, but possibly an early rise of arteriolar resistance and pressure is a response to a flow that was at first unusually large.

Classification of Cases with Pulmonary Hypertension. Patients with a patent ductus and pulmonary hypertension appear to belong to two groups. (1) In the first the pressure has risen gradually as a result of the increased pulmonary flow. It is rare for the flow through the ductus to become reversed and when this happens (as in Case 19) it is only after a long period when the shunt has been in the normal direction. The diagnosis can be made on clinical grounds by the continuous murmur.

(2) In the second group the pulmonary arterial pressure has been high from birth or from early infancy. It has been suggested that the pulmonary hypertension is congenital in this group and this 
view was accepted by Campbell and Hudson (1951) but it seems more likely that the arteriolar resistance and pressure rise unusually quickly because of the increased flow. The diagnosis may be suspected when there is pulmonary hypertension but can be made with certainty only by catheterization because they do not have a continuous murmur but only a systolic murmur, occasionally with a softer diastolic murmur of pulmonary regurgitation.

Group 1. There are not many reported cases with a balanced or reversed shunt where it can be said with certainty that they belong to this group. Holman (1925 and 1937) suggested that the shunt was reversed in many patients with cyanosis and right ventricular hypertrophy but probably the latter was secondary to pulmonary hypertension and the cyanosis was due to terminal failure and not to a reversed shunt. This view was taken by Wright and de Nevasquez (1942) in reporting the case of such a woman who died at the age of 57 years. Brown (1950) considers that reversal of the shunt is rare and with this we agree for Case 19 is the only certain one that we have seen, apart from those in Group 2.

A rising pulmonary pressure with the disappearance of the murmur in diastole, as in our Case 18, is more common and it is easy to see how such cases can be missed. There are many more where the pressure was rising to a level where this seemed likely in the future (e.g. Cases 11, 22, and 23) sometimes even in young patients (Cases 25-27).

The case of Harris (1955) certainly belongs to this group and probably Cases 6, 7, and 8 of Hultgren et al. (1953) and the case of Johnson et al. (1950) though a history of hæmoptysis when she was only 6 suggests pulmonary hypertension from infancy; in the last, however, there was still a left-to-right shunt and sometimes a reversed shunt through the ductus. It is difficult to be certain about some others partly because nothing is said about the presence or absence of a continuous murmur at an earlier stage.

Group 2.-Several patients who probably belong to this group have been reported recently. Among them are our Cases 28-33, some of the 4 cases of Alverez et al. (1950), the 3 of Cosh (1953), the 4 of Dammann et al. (1953), the first 4 of Hultgren et al. (1953), the cases of Novello et al. (1950), of Smith (1954), and of Emslie-Smith et al. (1955), and the 8 cases of Whitaker et al. (1955). If so, many of them stand the pulmonary hypertension well for years, for 16 of 23 were over 20 years of age and many did not have severe symptoms till the third decade. Even so it seems more likely that the woman aged 58 (Case 4 of Whitaker et al.) belongs to the first group and had an ordinary left-to-right shunt at first and developed pulmonary hypertension later.

The Reversibility of Pulmonary Hypertension. A high pressure in the pulmonary artery can revert to normal after the ductus has been closed. Thus in our three Cases 25-27 it fell from an average of $77 / 42$ to $23 / 11 \mathrm{~mm}$. Hg. This proves that the increased pulmonary flow is the cause, directly or indirectly, of the pulmonary hypertension. Other cases have been reported from time to time. Chávez et al. (1953b) reported two children aged 6 and 12 years where pulmonary arterial pressures of 68/41 and 104/63 fell to normal some months after operation, and Voci et al. (1951) reported one where it had fallen from over 50 to normal. In Case 7 of Hultgren et al. (1953), who was aged 33 years, it fell from 100/62 to $71 / 46 \mathrm{~mm}$. one month after operation. Myers et al. (1951) reported two children where operations produced a good result although the pulmonary pressure was over 80 and near that in the aorta, but they were not recatheterized.

The fall of pulmonary arterial pressure may be immediate. Thus in our Case 27 it fell from $50 / 35$ to $38 / 16$ as soon as the ductus was closed, and in another child, aged 2, where it was 53/39 at catheterization, it fell from 64/44 to 36/14 at once. In one case of Bonham-Carter et al. (1955) it fell from $88 / 55$ to $48 / 55$ as soon as the ductus was closed. The observations of Cournand $e t a l$. (1949) suggest that pulmonary hypertension may be reversed even where there are structural changes in the lungs, for in one child a pressure of $60 / 36$ was still $63 / 13$ five weeks after operation, but had fallen to $32 / 5$ after five months.

On the other hand, Chávez et al. (1953b) found some patients where the pressure had fallen considerably but not to normal. Thus in two children, aged 6 and 8 , it had fallen from 109/68 to $51 / 11$, and from 101/57 to 70/36; and in a patient of 27 , from $69 / 36$ to $40 / 14$. Catheterization was 
repeated after only two to four months so that the pressure might have fallen further. However, in a patient aged 33, where it was repeated after eleven months, it had fallen only from $103 / 57$ to 59/30. The most disappointing patient was one aged 11, where it had risen from 103/57 to 145/74 after nineteen months, in spite of closing the ductus, but she may have belonged to Group 2.

It is important to know if equally good results can be obtained even after the flow through the ductus has become reversed: it seems that often it may be too late. Three of the patients of Chávez et al. $(1953 b)$ just quoted were greatly improved by operation though the shunts were sometimes reversed, and in another girl who has not been recatheterized, the result of closing the ductus has been excellent, although the systolic and diastolic pressures were $22 \mathrm{~mm}$. and $12 \mathrm{~mm}$. higher in the pulmonary artery than in the aorta. Against these favourable cases there were three deaths: a girl of 16 , cyanotic from birth, with a pulmonary pressure of $136 / 68$, died at once from a tear in the pulmonary artery; a woman, aged 30, with a pulmonary pressure of 103/76 and a reversed shunt died two days after operation with acute cor pulmonale; and a child died some hours after operation with severe disturbances of the heart rhythm. Death followed closure of the ductus in the case of Smith (1954) although the pulmonary pressure became lower when it was occluded, and in a case reported by Novello et al. (1950) and in our Case 19. Case 1 of Dammann et al. (1953) died at operation before the ductus had been ligated. The case of Johnson et al. (1950) died five days after operation but the ductus had recanalized. There are, however, not enough reported cases to prove the pressure is irreversible even at this late stage and it seems that every case, whether successful or not, should be recorded for the present.

These patients show that a high pulmonary pressure can fall when the ductus is closed, as it does after a successful mitral valvotomy; this means that there are, as a general rule, no irreversible changes in the pulmonary arteries. The speed with which it can fall shows that in many cases there are no structural changes in the pulmonary arteries, though there is some evidence that, even when there are such changes, they may still be reversible.

On the present evidence it is unwise to assume that pulmonary hypertension is irreversible in any child with a patent ductus. The unusually high pressures seem to be an individual response to a large flow and not an independent pulmonary hypertension dating from birth. We think that every uncomplicated patent ductus should be closed, unless there is evidence that it is already closing, but agree with Chávez et al. (1953b) that where the pulmonary pressure is so high that the shunt is reversed, there are great dangers in either course and, ideally, it should have been closed earlier before the pressure had risen so high.

\section{SUMmaRY AND CONCLUSIONS}

Some patients with a patent ductus arteriosus may show a diminishing murmur and a freedom from signs and symptoms that shows the ductus is almost or completely closed. A few with classical signs and a large shunt may reach 50 or 60 years of age with few symptoms. Many, however, get increasing symptoms, a larger heart, and left ventricular strain about the fourth decade, and may develop heart failure. Probably more than have been recognized develop a balanced shunt and lose the murmur in diastole, but reversal of the shunt is rare, though possible.

The exact proportions in these groups could be settled only by following up a series of cases seen from childhood and this would have to be done for thirty years since most children make good progress with few complications for many years. We have described 20 patients over 35 years and it seems from these and from other reports that the number deteriorating in the third or fourth decades is a valid reason, quite apart from the risk of bacterial endocarditis, for advising that all patients should have a patent ductus closed, unless there are reasons for thinking that it is closing spontaneously.

The pulmonary arterial pressure is very variable. It is often normal but may rise to high levels even in young children of 3 years or less; it may rise as the patient gets older or it may still be normal though there has been a large shunt through the ductus for 60 years. In younger patients a high pulmonary arterial pressure can certainly be reduced to normal by closing the ductus and is a reason 
for operation rather than a contra-indication. So far there are few successful operations and several deaths in patients where the pressure has risen enough to reverse the flow, but in children at any rate the possibility of success should not be neglected.

There is, however, another group where the pressure has risen in infancy and the flow has been balanced or reversed since then. We have seen 6 of these cases during the time that we have seen 160 ordinary cases. If these patients are not seen till many years later, it seems too late to reverse the high pressure by closing the ductus, since there may be a high pulmonary arteriolar resistance and extensive structural changes in the pulmonary arterioles. If, however, they are recognized early, this may not be true, for they may be essentially the same as the others and differ only because an unusually large flow has led to a rise of pulmonary arterial pressure in infancy.

I am greatly indebted to the surgeons who have made this paper possible-to Mr. Brain who has operated on the larger number, to Mr. Ian Hill, to Mr. Holmes Sellors, and especially to Sir Russell Brock who has operated on most of the older patients and has asked me to see several of them with him.

I am grateful to Dr. Charles Baker for giving me the opportunity of seeing Cases 3, 10, and 29, to Dr. Brigden for Case 33, and to Dr. Paul Wood for Case 14 and also for the catheter results in this case, to Dr. Goetz for those in Case 19, and to Dr. Deuchar and Dr. Shephard for most of the others. I should like to thank Dr. Hudson for the necropsy report of Case 20 and for the photograph in Fig. 9.

Aitken, G. (1953). Brit. Heart J., 15, 463.

\section{REFERENCES}

Alverez, V. R., Limón, R., and Bouthard, F. (1950). 1e Congrés Mondial de Cardiologie, Communications, 270.

Benn, J. (1947). Brit. Heart J., 9, 283.

Bonham-Carter, R. E., Walker, C. H. M., Daley, R., Matthews, M. B., and Medd, W. E. (1955). Brit. Heart J., $17,255$. Bourne, G. (1945). Brit. Heart J., 7, 91.

Brown, J. W. (1950). Congential Heart Disease. 2nd ed., Staples Press, London.

Bullock, L. T., Jones, J. C., and Dolley, F. S. (1939). J. Pediat., 15, 786.

Campbell, M., and Hudson, R. (1951). Guy's Hosp. Rep., 100, 26.

- (1952). Guy's Hosp. Rep., 101, 32

Chávez, I., Cabrera, E., and Limón, R. (1953a). Arch. Inst. Cardiol. Mex., 23, 131. , Vela, J. E., Limón, R., and Dorbecker, N. (1953b). VII International Congress of Pediatry.-La Habana.

Cosh, J. A. (1953). Brit. Heart J., 15, 423.

Cournand, A., Baldwin, J. S., and Himmelstein, A. (1949). Cardiac Catheterization in Congenital Heart Disease. The Commonwealth Fund, New York.

Dammann, J. F., Jr., Berthrgon, M., and Bing, R. J. (1953). Bull. Johns Hopk. Hosp., $92,128$.

Dexter, L., Haynes, F. W., Burwell, C. S., Eppinger, E. C., Sosman, M.C., and Evans, J. M. (1947). J. Clin. Invest., 26, 561 .

East, T. (1945). Brit. Heart J., 7, 95.

Emslie-Smith, D., Hill, I. G. W., and Lowe, K. G. (1955). Brit. Heart J., 17, 79.

Gilchrist, A. R. (1945). Brit. Heart J., 7, 1 .

Gorlin, R. (1954). Brit. Heart J., 16, 739.

Gross, R. E. (1952). Amer. J. Med., $12,472$.

- and Hubbard, J. P. (1939). J. Amer. med. Ass., 112, 729.

Haring, O. M., Luisada, A. A., and Gasul, B. M. (1954). Circulation, 10, 501.

Harris, P. (1955). Brit. Heart J., 17, 85.

Holman, E. (1925). Bull. Johns Hopk. Hosp., 36, 61. (1937). Arteriovenous Aneurysms. London.

Hultgren, H., Selzer, A., Purdy, A., Holman, E., and Gerbode, F. (1953). Circulation, 8, 15.

Johnson, R. E., Wermer, P., Kirschner, M., and Cournand, A. (1950). Circulation, 1, 1293.

Keys, A., and Shapiro, M. J. (1943). Amer. Heart J., 25, 158.

Milstein, B. B., and Brock, R. C. (1954). Guy's Hosp. Rep., 103, 249.

Myers, G. S., Scannel, J. G., Wyman, S. M., Dimond, E. G., and Hurst, J. W. (1951). Amer. Heart J., $41,819$.

Novello, S., Limón, R., and Rouchard, F. (1950). 1e Congrés Mondial de Cardiologie, Communications, 264.

Shephard, R. J. (1954). Brit. Heart J., 16, 361. (1955). Guy's Hosp. Rep., 104, 46.

Smith, G. (1954). Brit. Heart J., 16, 233.

Storstein, O., Humerfelt, S., Müller, O., and Rasmussen, H. (1952). Brit. Heart J., 14, 276.

Voci, G., Touche, M., and Joly, F. (1951). Arch. Mal. Cour., 44, 1103.

Welch, K. J., and Kinney, T. D. (1948). Amer. J. Path., 24, 729.

Whitaker, W., Heath, D., and Brown, J. W. (1955). Brit. Heart J., 17, 121.

Wilson, M. G., and Lubschez, R. (1942). J. Pediat., 21, 23.

Wood, P. (1950). Brit. med. J., 2, 639 and 693.

Wright, G. P., and de Nevasquez, S. (1942). Guy's Hosp. Rep., 91, 69. 